\title{
Investor Sentiment, Limited Arbitrage, and the Cash Holding Effect*
}

\section{Xiafei $\mathrm{Li}^{1}$ and Di Luo ${ }^{2}$}

\author{
${ }^{1}$ University of Nottingham and ${ }^{2}$ Swansea University
}

\begin{abstract}
We examine the investor sentiment and limits-to-arbitrage explanations for the positive cross-sectional relation between cash holdings and future stock returns. Consistent with the investor sentiment hypothesis, we find that the cash holding effect is significant when sentiment is low, and it is insignificant when sentiment is high. In addition, the cash holding effect is strong among stocks with high transaction costs, high short selling costs, and large idiosyncratic volatility, indicating that arbitrage on the cash holding effect is costly and risky. In line with the limits-toarbitrage hypothesis, high costs and risk prevent rational investors from exploiting the cash holding effect.
\end{abstract}

JEL classification: G12, G14, G32

Keywords: Cash holdings, Investor sentiment, Transaction costs, Idiosyncratic volatility

\section{Introduction}

Asset pricing theories suggest that higher returns should be compensation for higher systematic risk. However, a number of studies provide empirical evidence on anomalies that cannot be explained by the capital asset pricing model (CAPM) of Sharpe (1964) and Lintner (1965), and the Fama and French (1993) three-factor model. ${ }^{1}$ In particular, recent studies by Palazzo (2012) and Simutin (2010) document a cash holding effect that firms with high cash-to-assets ratios or excess cash outperform firms with low cash ratios or excess cash significantly, even after adjusting for the Fama and French's (1993) three factors. They attribute the strong stock return performance of firms with high cash holdings to risk

*We thank an anonymous referee, the editor (Burton Hollifield), David Paton, and David Newton for their helpful comments. The project was supported by the Nottingham University Business School Spark Fund. All remaining errors are our own.

1 See, for example, price momentum (Jegadeesh and Titman, 1993), value premium (Fama and French, 1992; Lakonishok, Shleifer, and Vishny, 1994), accruals (Sloan, 1996), net operating asset (Hirshleifer et al., 2004), idiosyncratic volatility (Ang et al., 2006, 2009), investment-to-assets (Titman, Wei, and Xie, 2004; Xing, 2008), financial distress (Campbell, Hilscher, and Szilagyi, 2008), asset growth (Cooper, Gulen, and Schill, 2008), and profitability (Novy-Marx, 2013; Ball et al., 2015). 
caused by a high correlation between cash flows and the aggregate shock, or risk of firms' growth options.

In this study, we examine the investor sentiment and limits-to-arbitrage explanations for the cash holding effect. Our motivation follows Baker and Wurgler (2006), who suggest that both investor sentiment and limited arbitrage can lead to market mispricing because investor sentiment as the propensity to speculate can drive the demand for speculation. Baker and Wurgler (2006) show that stock returns of certain firms, such as firms with small size, negative operating profits, non-dividend paying, financial distress, or extreme growth potential, are highly affected by investor sentiment. These characteristics tend to coincide with those of high cash firms. ${ }^{2}$ Therefore, market mispricing is likely to happen in firms with high or low cash holdings.

In addition, Shleifer and Vishny (1997) develop a limits-to-arbitrage argument to understand anomalies. They argue that anomalies cannot be removed immediately because transaction costs and idiosyncratic volatility impose barriers against arbitrage (Pontiff, 1996, 2006). The literature has shown strong supports for this argument to explain different anomalies. For example, Ali, Hwang, and Trombley (2003) find that the book-to-market effect is concentrated in firms with high transaction costs and large idiosyncratic volatility. Mashruwala, Rajgopal, and Shevlin (2006) and Hirshleifer, Teoh, and Yu(2011) show that great idiosyncratic volatility, high transaction costs, and short-sale constraints prevent rational traders from exploiting the accrual anomaly. Li and Zhang (2010), Lam and Wei (2011), and Lipson, Mortal, and Schill (2011) highlight the limits-to-arbitrage explanation for the asset growth anomaly. McLean (2010) reports that the long-term reversal anomaly is related to limits-to-arbitrage. Brav, Heaton, and Li (2010) demonstrate that limits-toarbitrage plays an important role in explaining overvaluation anomalies. McLean and Pontiff (2016) study ninety-seven anomalies and find that mispricing accounts for the predictability of characteristics on the cross-sectional stock returns. Surprisingly, little empirical research has addressed the investor sentiment and limits-to-arbitrage explanations on the cash holding effect. This article intends to fill this gap.

We hypothesize that irrational investors may make systematic errors when they value firms with different levels of cash holding. They are pessimistic about the future earnings, the degree of information asymmetry, and agency costs of high cash firms and optimistic about these of low cash firms. As a result, irrational investors may undervalue firms with high cash holdings and overvalue firms with low cash holdings. Rational investors recognize trading firms with different levels of cash holding as an arbitrage opportunity. However, high transaction costs, high short-selling costs, and large idiosyncratic volatility prevent rational investors from exploiting the profit opportunity of cash holding trading strategy and eliminating the mispricing quickly. We, therefore, examine two important questions: (i) Are stock returns of firms with different levels of cash holding highly influenced by investor sentiment? (ii) Is the cash holding effect associated with high transaction costs, high short-selling costs, and large idiosyncratic volatility?

We use two cash holding measures of cash-to-assets ratio (Palazzo, 2012) and excess cash (Simutin, 2010), and two investor sentiment measures of the Baker and Wurgler investor sentiment index and the University of Michigan Consumer Sentiment Index.

2 See, for example, Kim, Mauer, and Sherman (1998), Opler et al. (1999), Bates, Kahle, and Stulz (2009), Simutin (2010), and Palazzo (2012). 
Following a number of existing studies, ${ }^{3}$ our limits-to-arbitrage proxies include transaction costs, short selling costs, and idiosyncratic volatility.

Consistent with Palazzo (2012) and Simutin (2010), we find that high cash firms outperform low cash firms in stock returns significantly, regardless of the cash holding measures. More importantly, the stock returns of cash holding portfolios are highly influenced by investor sentiment. When sentiment is low, the returns of cash holding portfolios are larger than those when sentiment is high across both the cash holding measures and the two sentiment indices. With only one exception, the cash holding effect is significant when sentiment is low, and it is insignificant when sentiment is high. This is in line with the investor sentiment explanation.

Using a two-way independent sorts approach, based on the limits-to-arbitrage proxies and the cash holding measures, we find that the cash holding effect is stronger for stocks with higher transaction costs, higher short selling costs, and larger idiosyncratic volatility. Using Fama and MacBeth's (1973) cross-sectional regressions, our results show that the coefficients of the cash holding variable are significantly larger in magnitude in firms with high transaction and short selling costs, and great idiosyncratic volatility than in firms with low costs and idiosyncratic volatility. The results suggest that arbitrage on the cash holding effect is costly and risky.

The rest of this article is organized as follows. Section 2 develops the investor sentiment and limits-to-arbitrage hypotheses for the cash holding effect. Section 3 describes data used in this study, the measures of cash holding, and the proxies for investor sentiment and limits-to-arbitrage. Section 4 presents the empirical results. Section 5 concludes the article.

\section{Hypothesis Development}

Firms with high cash holdings are likely to have poor past operating performance. Investors may make systematic errors in expectations about future prices of those stocks because their valuations are highly subjective. High transaction costs, high short selling costs, and large idiosyncratic volatility make arbitrage on the cash holding effect costly and risky. In this section, we develop our hypotheses of investor sentiment and limits-to-arbitrage on firms with different levels of cash holding based on Baker and Wurgler (2006) and Shleifer and Vishny (1997).

\subsection{Investor Sentiment}

Investors are not fully rational. They may trade securities according to their beliefs based on past earnings and investment risks. As a result, markets are highly influenced by investor

3 See, for example, Mitchell and Pulvino (2001) use direct and indirect trading costs to capture transaction costs for limit-to-arbitrage. Ali, Hwang, and Trombley (2003) show that the book-to-market effect is larger for stocks with higher transaction costs measures of bid-ask spread, brokerage commissions, dollar trading volume, and costs of short selling. Mashruwala et al. (2006) report that the accrual anomaly is stronger for stocks with lower trading volume. Li and Zhang (2010) and Lam and Wei (2011) also examine the limits-to-arbitrage hypothesis in explaining asset growth anomaly through transaction costs measures, including bid-ask spread, institutional ownership, price impact, and dollar trading volume. Mitchell, Pulvino, and Stafford (2002) and Doukas, Kim, and Pantzalis (2010) find that costs of short-selling are particularly high and deter arbitrageurs from exploring arbitrage opportunities. 
sentiment (Barberis, Shleifer, and Vishny, 1998; Baker and Wurgler, 2007). Baker and Wurgler (2006) find that investors mark stocks with low past earnings and nondividend paying as speculative stocks, while they mark stocks with high profitability and stable dividends as safe stocks. They have low propensity to speculate for safe stocks and high propensity to speculate for speculative stocks. Bates, Kahle, and Stulz (2009), Simutin (2010) and Palazzo (2012) show that firms with high cash holdings are likely to be speculative stocks, while firms with low cash holdings tend to be safe stocks according to their characteristics. Hence, returns of stocks with high and low cash holdings might be highly sensitive to speculative demand.

Moreover, Opler et al. (1999) argue that firms increasing cash holdings might result from their high degrees of information asymmetry. Faulkender and Wang (2006) and Denis and Sibilkov (2010) prove that financially constrained firms have high levels of information asymmetry and are likely to save larger amounts of cash. Jensen (1986) proposes that the agency problem is particularly severe for a firm with large free cash flow. Dittmar, MahrtSmith, and Servaes (2003) show that firms in countries with greater agency problems tend to hold more cash. Harford (1999), Dittmar and Mahrt-Smith (2007), Harford, Mansi, and Maxwell (2008) and Nikolov and Whited (2014) also find that firms with high cash holdings have high agency costs on acquisition. Therefore, investors may overreact to bad news of firms with high cash holdings and underreact to good news of firms with low cash holdings because of their pessimism and optimism about future earnings, information asymmetry, and agency costs of firms with different levels of cash holding. We therefore hypothesize that stock returns of firms with high and low cash holdings might be heavily affected by investor sentiment.

\subsection{The Limits of Arbitrage}

Sharpe and Alexander (1990) define arbitrage as exploring price differences on the same or similar securities by buying underpriced stocks and shorting substitutes or overpriced stocks simultaneously. In this section, we discuss the impact of transaction costs, short selling costs, and idiosyncratic volatility on arbitrage activities.

\subsubsection{Transaction costs and arbitrage}

Investors incur transaction costs, such as brokerage fees, commissions, and market impact when they buy or sell securities. Shleifer and Vishny (1997) and Pontiff $(1996,2006)$ show that transaction costs create the bounds that limit the ability of rational investors to eliminate market mispricing. Many studies use transaction costs as proxies for limits-to-arbitrage. For example, Ali, Hwang, and Trombley (2003) examine limits-to-arbitrage on the bookto-market anomaly using three types of transaction costs: direct, indirect, and costs related to short selling. Mashruwala, Rajgopal, and Shevlin (2006) use stock price and trading volume to capture transaction costs.

\subsubsection{Short selling costs}

Ali, Hwang, and Trombley (2003) argue that short-sale has an impact on costs of arbitrage. To sell short, a rational investor has to borrow a stock from the owner of the stock and leave collateral for the borrowing. Dechow et al. (2001) point out that short sellers suffer from short squeeze risk because they must repurchase the borrowed stock if the original lender requires the borrowing position to be closed. Stocks with high institutional 
ownership have low short squeeze risk and low short selling costs because it is easy to find alternative lenders who own the stocks. Nagel (2005) also argues that low institutional ownership leads to a shortage of supply for stocks that can be borrowed and results in high short selling costs.

\subsubsection{Idiosyncratic volatility and arbitrage}

Shleifer and Vishny (1997) emphasize that arbitrage resources are mainly available to a few specialized traders. They are poorly diversified and more concerned with idiosyncratic volatility than systematic volatility because the former cannot be hedged. As stocks are not rationally priced, high idiosyncratic volatility makes arbitrage less attractive, particularly for some volatile and overpriced stocks. Therefore, idiosyncratic volatility prevents rational investors from exploiting the mispricing.

Pontiff (2006) argues that, apart from transaction costs, holding costs also make arbitrage more expensive. He identifies idiosyncratic volatility as a part of holding cost of arbitrage, which has an impact on both mispricing and the selling decision of rational investors. Implementing an arbitrage strategy involves simultaneously buying the underpriced stocks and shorting the overpriced stocks. Hence, the returns on the arbitrage portfolio do not comove with the market returns, and arbitrage strategy is only subject to idiosyncratic volatility. For a mean-variance investor, the optimal portfolio weights are negatively related to idiosyncratic volatility. Rational investors would hold fewer positions in stocks with high idiosyncratic volatility and result in less selling pressure for these stocks. Therefore, firms with high idiosyncratic volatility have high holding costs.

\section{Data and the Measures}

We use common stocks listed on the NYSE, AMEX, and NASDAQ from the period of July 1972 to June $2011 .{ }^{4}$ We exclude heavily regulated utility firms (SIC codes between 4900 and 4999) and financial firms (SIC codes between 6000 and 6999). Monthly and daily stock returns, stock prices, the number of shares outstanding, and trading volume are collected from the Center for Research in Security Prices (CRSP). Accounting data are obtained from the Compustat database. Quarterly institutional stock holdings are from the Thomson Financial Institutional Holdings (13F) database. We exclude stocks with a negative book-to-market ratio or a negative cash-to-assets ratio. For delisted stocks, we use the CRSP delisting returns if they are available; otherwise, we follow Shumway (1997) to adjust missing delisting returns if the delisting is performance-related. The daily and monthly return series of the Fama and French (1993) three factors, including size, book-to-market, and market excess returns, and risk-free rates are from Kenneth French's website. ${ }^{5}$ We collect two sentiment indices: the Baker and Wurgler (2006) investor sentiment index from Jeffrey Wurgler's website and the University of Michigan Consumer Sentiment Index from Federal Reserve Bank of St Louis. ${ }^{6}$

4 The beginning period of our sample is consistent with Palazzo (2012). We identify common stocks as those with CRSP share code 10 and 11.

5 http://mba.tuck.dartmouth.edu/pages/faculty/ken.french/.

6 http://people.stern.nyu.edu/jwurgler/. and http://research.stlouisfed.org/. 


\subsection{Cash Holding Measures}

Our first cash holding measure is the monthly cash-to-assets ratio. Following Palazzo (2012), this is calculated as cash and marketable securities (data item CHEQ) over total assets (data item ATQ) using the accounting data from the latest quarter. ${ }^{7}$ The second cash holding measure is the excess cash defined as the residual from the following crosssectional regression of the log of cash-to-assets ratios against the determinate variables highlighted by Opler et al. (1999):

$$
\begin{aligned}
C_{i, t}= & \gamma_{0, t}+\gamma_{1, t} M B_{i, t}+\gamma_{2, t} \operatorname{Size}_{i, t}+\gamma_{3, t} C P X_{i, t}+\gamma_{4, t} W_{i, t}+\gamma_{5, t} L T D_{i, t} \\
& +\gamma_{6, t} R D_{i, t}+\gamma_{7, t} C F_{i, t}+\gamma_{8, t} \sigma_{i, t}^{I N D}+\gamma_{9, t} I N D d u m m y_{i, t}+\gamma_{10, t} D_{i v d u m m y}+\varepsilon_{i, t},
\end{aligned}
$$

where $C$ is the log of cash-to-assets ratio, measured as cash (data item $\mathrm{CHE}$ ) divided by total assets (data item $A T$ ) less cash; $M B$ is the market-to-book ratio calculated as the book value of assets, minus the book value of equity (data item CEQ), plus the market value of equity, divided by the book value of assets; Size is the log of total assets that have been adjusted for inflation; CPX is the ratio of capital expenditures (data item CAPX) over total assets; WC is the ratio of net working capital over total assets. We calculate net working capital by subtracting cash from working capital (data item WCAP). LTD is the ratio of long-term debt (data item $D L T T$ ) over total assets; $R \& D$ is the ratio of research and development expense $(R \& D)$ (data item $X R D$ ) over sales (data item $S A L E$ ); $C F$ is the ratio of cash flow over total assets. We estimate cash flow as operating income after interest, dividends, and taxes, but before depreciation (data item OIBDP - DVC - TXT - XINT). $\sigma^{I N D}$ is the industry sigma calculated as the mean of standard deviations of CF over 10 years for firms in the same two-digit SIC industry. Following Simutin (2010), we also include industry dummies (INDdummy) based on Kenneth French's 17 industry definitions and a dividend dummy (Divdummy). The residual, $\varepsilon_{i, t}$, from Equation (1) is the excess cash measure (ECM) for stock $i$ in year $t$.

\subsection{Transaction Costs Measures}

Following Ali, Hwang, and Trombley (2003), we employ three transaction costs measures: the quoted bid-ask spread of Amihud and Mendelson (1986), the price impact of Amihud (2002), and dollar trading volume. They are calculated as the average daily measure over the prior 12 months. The quoted bid-ask spread $(B A)$ is estimated as the difference between the quoted ask price and bid price to the mid-quote on a particular day. ${ }^{8}$ It represents compensation to the market maker or dealer for a round-trip transaction (purchase and sale). Stocks with high $B A$ are more costly than stocks with low $B A$. Price impact $(P I)$ is defined as the daily absolute return-to-dollar-volume ratio. It captures the reaction of transaction

7 For instance, to estimate the cash-to-assets ratios of month-1, 2, or 3 in year $t$ for a stock, we use the 4 th quarter data in year $t-1$. Again, to estimate the ratios of month-4, 5 , or 6 in year $t$, we use the 1st quarter data in year $t$.

8 For NYSE/Amex stocks, the CRSP daily bid and ask prices are closing bid and closing ask prices, whereas NASDAO uses the inside quotation as the bid and ask prices. When the bid or ask prices of a stock are not available on a day, we use Bid or Low price, or Ask or High price from the CRSP as the bid and ask prices for the stock, respectively. We also calculate bid-ask spread using data from the Trade and Quote (TAQ) Database, which are obtained from: http://www.vanderbiltfmrc. org/databases/market-microstructure-database/. As our results show that the TAO BAs are highly correlated with the CRSP $B A s$, we do not report these results here. 
price to trading volume. Stocks with high $P I$ are more expensive to trade than stocks with low PI. Dollar trading volume $(D V)$ is calculated as the number of shares traded multiplied by the transaction price during a day. Trades are more likely to be completed quickly and lead to less adverse price impact if stocks are heavily traded. Therefore, stocks with high $D V$ are cheaper to trade than stocks with low $D V$.

We also use the percentage of institutional ownership (IO) divided by the number of shares outstanding using the data from the latest quarter to capture the costs of short selling. Dechow et al. (2001) argue that institutional ownership indicates stock supply to borrow in the equity loan market. Low institutional ownership implies a limited source available to borrow for a stock and high potential squeeze risk. Therefore, stocks with a low percentage of institutional ownership have large short selling costs.

\subsection{Idiosyncratic Volatility}

A number of studies employ the Fama and French (1993) three-factor model (hereafter FF3) to estimate idiosyncratic volatility (e.g., Xu and Malkiel, 2003; Bali et al., 2005; Bali and Cakici, 2008; Ang et al., 2006, 2009; Fu, 2009; and Huang et al., 2010). Following these studies, we measure the idiosyncratic volatility of each stock from the following Fama and French (1993) three-factor model:

$$
R_{i, \tau}-R_{f, \tau}=\alpha_{i}+\beta_{i, M K T}\left(R_{m, \tau}-R_{f, \tau}\right)+s_{i} S M B_{\tau}+h_{i} H M L_{\tau}+\varepsilon_{i, \tau}
$$

where $R_{i, \tau}$ is the return on stock $i$ at the end of day $\tau . R_{f, \tau}$ is the 1-month Treasury bill rate and $R_{m, \tau}$ is the value-weighted market return on all stocks listed on the NYSE, AMEX, and NASDAQ. $S M B_{\tau}$ (Small-Minus-Big) and $H M L_{\tau}$ (High-Minus-Low) are the returns on the mimicking portfolios for capturing the size and book-to-market equity effects. $\varepsilon_{i, \tau}$ represents the idiosyncratic return on stock $i$. We use the daily excess returns in Equation (2). The idiosyncratic volatility of a stock, denoted $I V O L_{F F 3}$, is calculated as the standard deviations of residuals from the FF3 regression over the prior 12 months with a minimum of 100 days, respectively.

Table I provides summary statistics and the correlation coefficients across the measures of cash holding, transaction costs, short selling costs, and idiosyncratic volatility. The cashto-assets measure $(\mathrm{CH})$ is significantly correlated with the excess cash measure $(E C M)$, with a correlation coefficient of 0.530 . Moreover, $\mathrm{CH}$ and ECM are negatively correlated with the transaction costs measures of the bid-ask spread $(B A)$ and price impact $(P I)$, and positively correlated with dollar volume $(D V)$. This suggests that low cash firms might have high transaction costs and low trading volume. Interestingly, we find the different correlations between $\mathrm{CH}$ and ECM with institutional ownership and idiosyncratic volatility. Specifically, there is a negative (positive) correlation between $\mathrm{CH}(E C M)$ and institutional ownership $(I O)$, while a positive (negative) correlation between $\mathrm{CH}(E C M)$ and $I V O L_{F F 3}$. This indicates that institutional ownership and idiosyncratic volatility are sensitive to the determinate variables of cash holding in Equation (1), which is in line with the finding of Nagel (2005) for the strong positive correlation between stock institutional ownership and firm size.

\section{Empirical Results}

\subsection{Descriptive Analysis for Cash Holding Portfolios}

We first investigate the return performance of cash holding portfolios. Following Palazzo (2012), we form cash-to-assets $(\mathrm{CH})$ portfolios on a monthly basis. Specifically, at the end 
Table I. Descriptive statistics

This table reports the mean, standard deviation (SD), minimum (Min), median, maximum (Max) and correlation of the measures of cash holding, transaction costs, short selling costs, and idiosyncratic volatility. We use two cash holding measures: cash-to-asset ratio $(\mathrm{CH})$ and excess cash measure $(E C M)$; three transaction costs measures: the quoted bid-ask spread $(B A, \%)$, price impact $\left(P I, 10^{6}\right)$, and dollar volume $(D V, 000)$; the short selling costs measure of the percentage of institutional ownership (IO), and the idiosyncratic volatility measure of $I V O L_{F F 3}$. $C H$ is calculated as cash and marketable securities (data item $C H E Q$ ) divided by total assets (data item $A T Q$ ). ECM is estimated as the residual from the cross-sectional regression of the log of cash-to-assets ratios against determinate variables suggested by Opler et al. (1999). BA is estimated as the difference between the quoted ask price and bid price to the mid-quote on a day. $\mathrm{Pl}$ is the price impact measure that is defined as the daily absolute return-to-dollar-volume ratio. $D V$ is calculated as the number of shares traded multiplied by the transaction price during a day. $I O$ is computed as the percentage of institutional ownership to shares outstanding. The idiosyncratic volatility measure is estimated as the standard deviations of the regression residuals from the Fama and French (1993) three-factor model using daily stock returns over prior 12 months with a minimum of 100 days, respectively. The mean, standard deviation, and Spearman rank correlations are based on the time-series cross-sectional averages. The $P$-values are in the parentheses. The sample includes all common stocks on the NYSE, AMEX, and NASDAQ with positive cash-to-assets ratios and positive book-to-market ratios for the period from July 1972 to June 2011. Financial firms (SIC codes 6000-6999) and utilities (SIC codes 4900-4999) are excluded from the sample.

\begin{tabular}{|c|c|c|c|c|c|c|c|}
\hline & $\mathrm{CH}$ & $E C M$ & $B A$ & $P I$ & $D V$ & IO & $I V O L_{F F}$ \\
\hline \multicolumn{8}{|c|}{ Descriptive statistics } \\
\hline Mean & 0.170 & 0.001 & 0.061 & 9.121 & 8612.944 & 0.332 & 0.034 \\
\hline SD & 0.216 & 1.467 & 0.091 & 206.756 & 62925.665 & 0.275 & 0.029 \\
\hline MIN & 0.000 & -11.770 & 0.000 & 0.000 & 0.000 & 0.000 & 0.000 \\
\hline MAX & 1.442 & 11.698 & 1.908 & 99410.109 & 6155167.000 & 1.000 & 1.871 \\
\hline \multicolumn{8}{|l|}{ Correlation } \\
\hline ECM & $\begin{array}{c}0.530 \\
(0.000)\end{array}$ & 1.000 & & & & & \\
\hline$B A$ & $\begin{array}{c}-0.071 \\
(0.000)\end{array}$ & $\begin{array}{c}-0.084 \\
(0.000)\end{array}$ & 1.000 & & & & \\
\hline PI & $\begin{array}{c}-0.026 \\
(0.000)\end{array}$ & $\begin{array}{c}-0.042 \\
(0.000)\end{array}$ & $\begin{array}{c}0.129 \\
(0.000)\end{array}$ & 1.000 & & & \\
\hline$D V$ & $\begin{array}{c}0.031 \\
(0.000)\end{array}$ & $\begin{array}{c}0.023 \\
(0.000)\end{array}$ & $\begin{array}{c}-0.084 \\
(0.000)\end{array}$ & $\begin{array}{c}-0.006 \\
(0.000)\end{array}$ & 1.000 & & \\
\hline$I O$ & $\begin{array}{c}-0.016 \\
(0.000)\end{array}$ & $\begin{array}{c}0.054 \\
(0.000)\end{array}$ & $\begin{array}{c}-0.418 \\
(0.000)\end{array}$ & $\begin{array}{c}-0.096 \\
(0.000)\end{array}$ & $\begin{array}{c}0.171 \\
(0.000)\end{array}$ & 1.000 & \\
\hline$I V O L_{F F 3}$ & $\begin{array}{c}0.136 \\
(0.000)\end{array}$ & $\begin{array}{c}-0.068 \\
(0.000)\end{array}$ & $\begin{array}{c}0.387 \\
(0.000)\end{array}$ & $\begin{array}{c}0.114 \\
(0.000)\end{array}$ & $\begin{array}{c}-0.063 \\
(0.000)\end{array}$ & $\begin{array}{c}-0.319 \\
(0.000)\end{array}$ & 1.000 \\
\hline
\end{tabular}

of each month of year $t$, we sort stocks based on their past month cash-to-assets ratio $(\mathrm{CH})$ and form ten deciles. We hold the portfolios for the subsequent month and rebalance them every month during the sample period. To form ECM portfolios, we modify Simutin's (2010) approach by sorting stocks into groups annually rather than monthly. In particular, at the end of June of year $t$, we sort stocks into ten ECM portfolios based on stocks excess 
cash measured by using accounting data from year $t-1$. The portfolios are held for the following 12 months and rebalanced annually.

Table II reports the equal-weighted monthly average raw returns, the abnormal returns from the CAPM (CAPM alpha), and the FF3 (FF3 alpha) for cash holding portfolios. ${ }^{9}$ We calculate the $t$-statistics based on Newey and West (1987) standard errors with six lags throughout the article. Panels A and B present the results under the cash-to-assets $(\mathrm{CH})$ and excess cash measures $(E C M)$, respectively. $\mathrm{CH}_{1}\left(E C M_{1}\right)$ represents the bottom cash-toassets (excess cash measure) decile and $\mathrm{CH}_{10}\left(E C M_{10}\right)$ represents the top cash-to-assets (excess cash measure) decile. $\triangle C H(\triangle E C M)$ represents a hedge portfolio that is long the top portfolio, $\mathrm{CH}_{10}\left(E C M_{10}\right)$, and shorts the bottom portfolio, $\mathrm{CH}_{1}\left(E C M_{1}\right)$. Panel A of Table II shows that the returns rise monotonically from portfolio $\mathrm{CH}_{1}$ to $\mathrm{CH}_{10}$. Moreover, $\mathrm{CH}_{10}$ outperform $\mathrm{CH}_{1}$ significantly, with $0.567 \%(t=2.21)$ per month for the raw return, and $0.937 \%(t=4.82)$ per month for the FF3 alpha. Consistent with Simutin (2010), Panel B of Table II suggests that the top ECM portfolio generates the highest returns and the bottom ECM portfolio yields the lowest returns across ECM deciles. In addition, the returns of the hedge portfolio, $\triangle E C M$, are significant at the $5 \%$ level across the three return performance measures.

Panel A of Table III presents firm characteristics of $\mathrm{CH}$ deciles. The reported firm characteristics are: excess cash measure $(E C M)$, market capitalization of equity $(M V$, in millions dollar), book-to-market ratio $(B / M)$, cash flow risk (CFR), profitability (Profit), leverage (Leverage), net investment (NetInv), dividend dummy (DivDummy), research and development expense to sales ratio $(R \& D)$, and acquisitions to assets ratio (Acquisition). We define a dividend dummy as one in years for a firm with dividend payout and zero otherwise. The detailed definitions of firm characteristics are reported in Appendix. Clearly, the ECMs increase monotonically from portfolio $\mathrm{CH}_{1}$ to portfolio $\mathrm{CH}_{10}$, suggesting that $\mathrm{ECM}$ portfolios are likely to have similar firm characteristics with $\mathrm{CH}$ portfolios. Therefore, we only examine them for $\mathrm{CH}$ portfolios.

Consistent with Opler et al. (1999), Bates, Kahle, and Stulz (2009), and Palazzo (2012), firms with the highest cash holdings tend to be small and growth firms (low $M V$ and $B / M$ ratios). They have high cash flow risk and generate negative income. Only $25.5 \%$ of firms in portfolio $\mathrm{CH}_{10}$ pay dividends. In addition, high cash firms have low spending on capital expenditure and high $R \& D$ ratio. Opler and Titman (1994) argue that firms with high $R \&$ $D$ ratios are likely to have large costs of financial distress due to their high sensitivity to customer-driven sale loss. Almeida, Campello, and Weisbach (2004) and Bates, Kahle, and Stulz (2009) find that firms with negative income and paying no dividends are likely to be financially constrained firms. Fazzari, Hubbard, and Petersen (1988), Morellec and Schürhoff (2011), and Li and Luo (2014) demonstrate that financially constrained firms have high degrees of information asymmetry. Our findings are in line with the hypothesis of Opler et al. (1999) that firms with high cash holdings have high degrees of information asymmetry because they are small distressed firms and have poor access to external funds. Therefore, they borrow less debt to finance their investments and have extremely low

9 The reported returns in this study are the equal-weighted returns. We also calculate the valueweighted returns for $\mathrm{CH}$ portfolios. Consistent with Palazzo (2012), the FF3 alpha of $\mathrm{CH}_{10}$ is significantly larger than that of $\mathrm{CH}_{1}$. For ECM portfolios, the value-weighted returns are misleading as they suffer from double counting problem for market capitalizations. We therefore do not report the value-weighted returns here. 


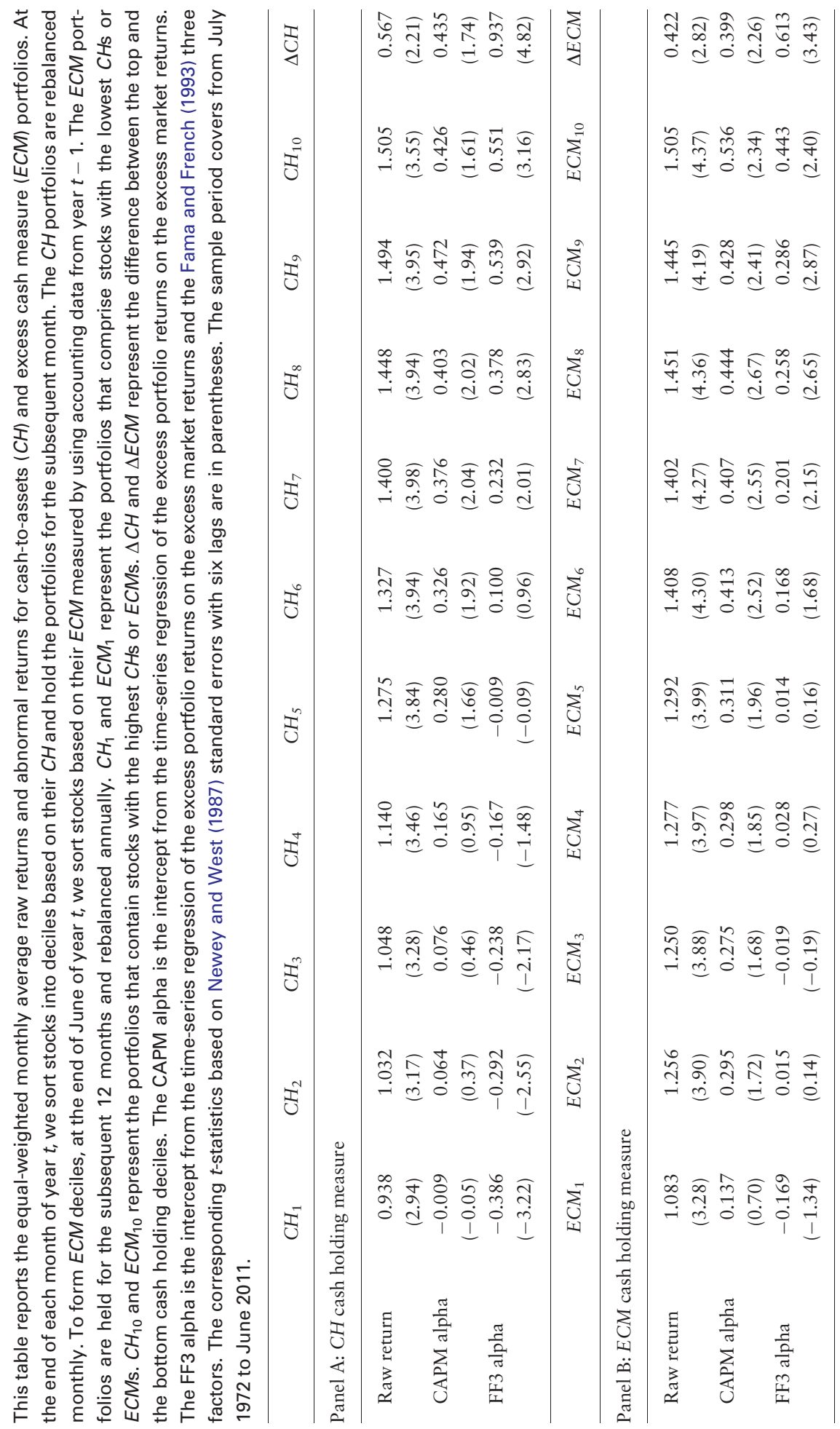




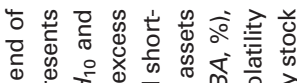

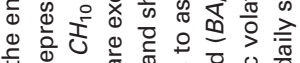

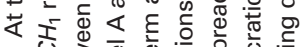
ن.

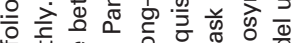

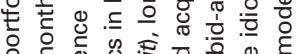

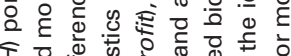

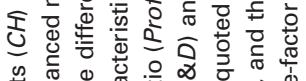

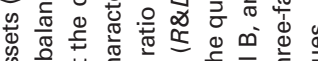
की

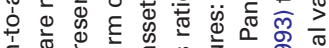

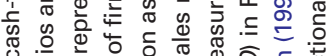

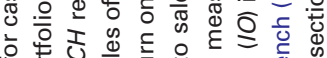

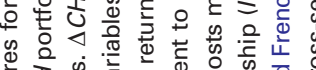

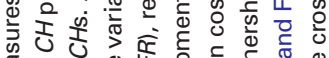

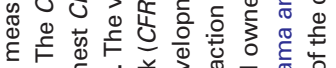

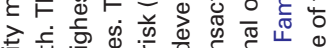

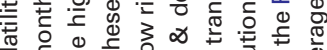

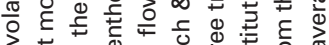

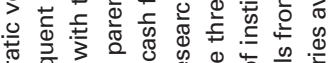

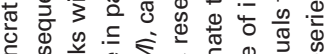

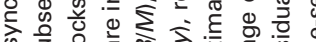
के के

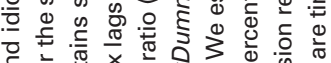
क产产

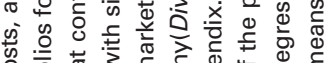

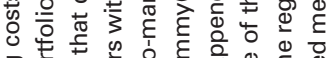

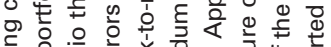

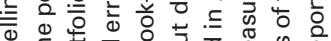

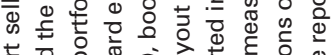
능 흥응 के की

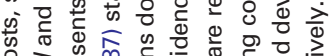

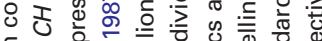
은

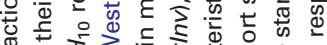

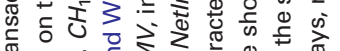

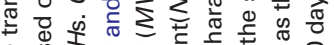

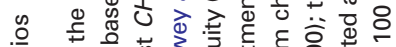

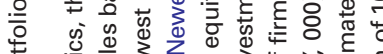
.

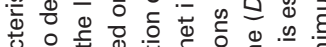

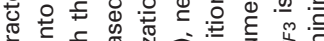

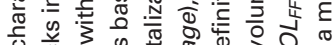

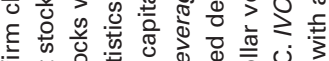

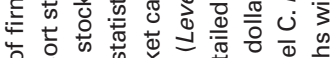

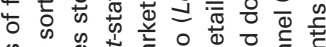
की बํ. ह 눙 눈 屯

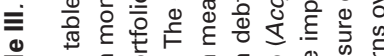

蕰
U্

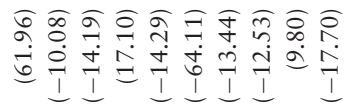

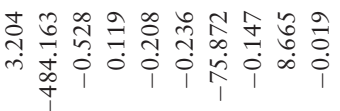

원

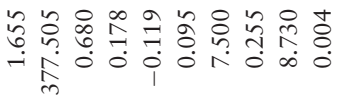

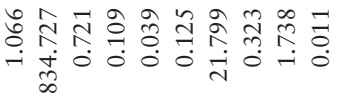

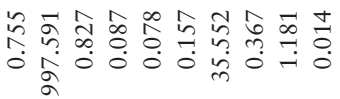

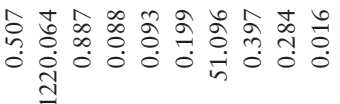

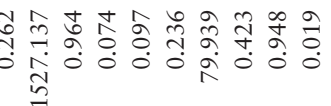

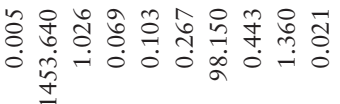

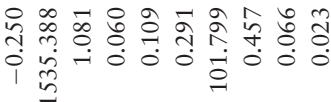

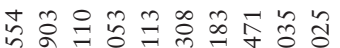

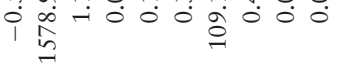

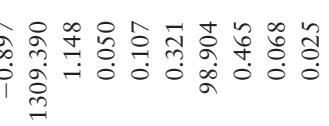

$\underset{U}{N}$

$\overrightarrow{5}$

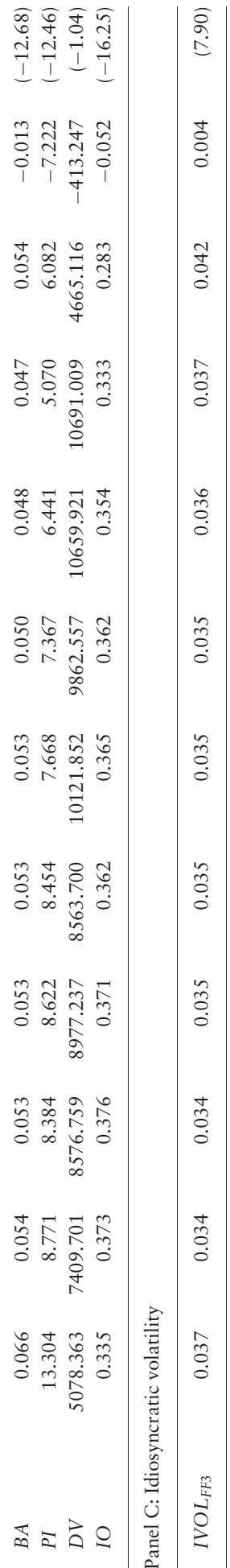


leverage. Conversely, firms with low cash holdings have low cash flow risk, produce positive profitability and have low $R \& D$ ratios, indicating low financial distress costs for low cash firms. Hence, they borrow more debt to take tax advantage. On average, $40.2 \%$ of firms in portfolio $\mathrm{CH}_{1}$ pay dividends to their shareholders.

Panel B of Table III reports the transaction costs and short selling costs measures, including the bid-ask spread $(B A)$, price impact $(P I)$, dollar volume $(D V)$, and the percentage of institutional ownership (IO) for $\mathrm{CH}$ portfolios. Portfolio $\mathrm{CH}_{10}$ has lower $\mathrm{BA}$ and PI than portfolio $\mathrm{CH}_{1}$, indicating that firms with the highest cash holdings have lower transaction costs than firms with the lowest cash holdings. This is consistent with the findings of Gopalan, Kadan, and Pevzner (2012) on the positive relation between asset liquidity and stock liquidity. Moreover, portfolio $\mathrm{CH}_{10}$ has lower $\mathrm{DV}$ and $\mathrm{IO}$ than portfolio $\mathrm{CH}_{1}$, suggesting that high cash firms have less trading volume and higher short selling costs than low cash firms.

Jensen and Meckling (1976) and Ang, Cole, and Lin (2000) show that agency costs of a firm are highly related to its ownership structure. Firms with more institutional ownership should have low agency costs as large shareholders play monitoring roles for management (Shleifer and Vishny, 1986). Our results on IO support the hypothesis that high cash firms have large agency costs due to their low $I O$, while low cash firms tend to have low agency costs. Panel $\mathrm{C}$ presents idiosyncratic volatilities for $\mathrm{CH}$ portfolios. The results indicate that firms with high cash holdings have larger idiosyncratic risk than firms with low cash holdings.

\subsection{Investor Sentiment for Cash Holding Portfolios}

Baker and Wurgler (2006) argue that investor sentiment can lead to market mispricing and has a significant impact on the cross-sectional stock returns, particularly for stocks with high sensitivity to speculative demand. They develop the Baker and Wurgler sentiment index from six sentiment proxies, including the closed-end fund discount, NYSE share turnover, the number of initial public offerings, the average first day's returns of initial public offerings, the equity share in new issue, and the dividend premium. To examine the role of sentiment in explaining the cash holding effect, we also use the University of Michigan Consumer Sentiment Index which is a consumer confidence measure. Lemmon and Portniaguina (2006) show that this measure can capture investor sentiment in stock mispricing.

Table IV displays the equal-weighted FF3 alphas for cash holding portfolios conditional on sentiment. Panels A and B report the results on $\mathrm{CH}$ and ECM decile portfolios, respectively. Following Baker and Wurgler (2006), we first put each monthly return of portfolios together. According to the level of sentiment at the end of the previous month, we calculate the average portfolio returns over the months in which sentiment is above and below the median based on the Baker and Wurgler (2006) investor sentiment index and the University of Michigan Consumer Sentiment Index. We also compute the return difference between above and below the median for each portfolio.

Our results show that both investor sentiment and consumer sentiment affect the returns on cash holding portfolios significantly. Specifically, the returns on $\mathrm{CH}$ portfolios are higher when the investor and consumer sentiment indices are below the median than when they are above the median. For instance, the FF3 alphas range from a low of $-0.233 \%$ to a high of $0.308 \%$ when investor sentiment is above the median, while they range from - 


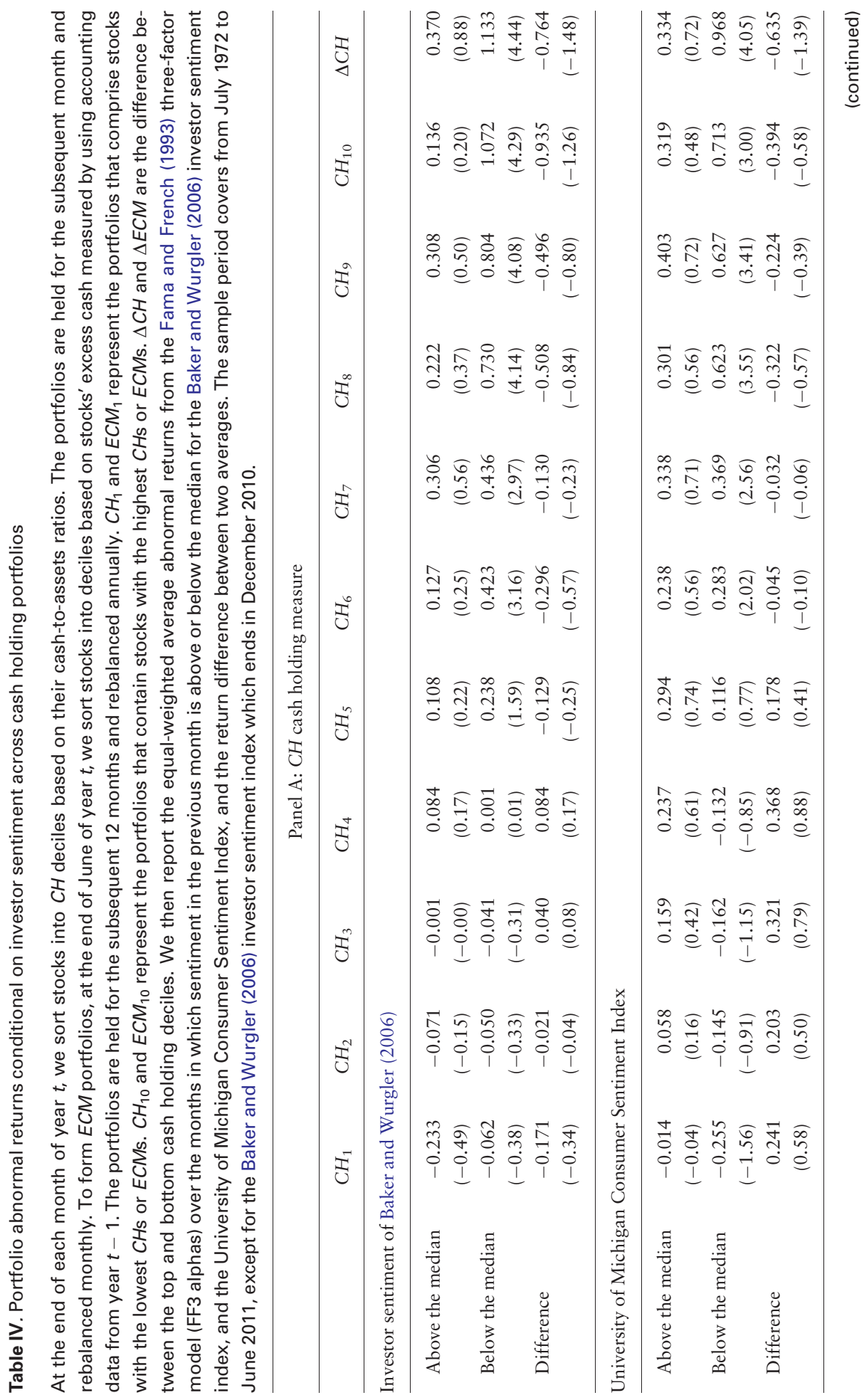




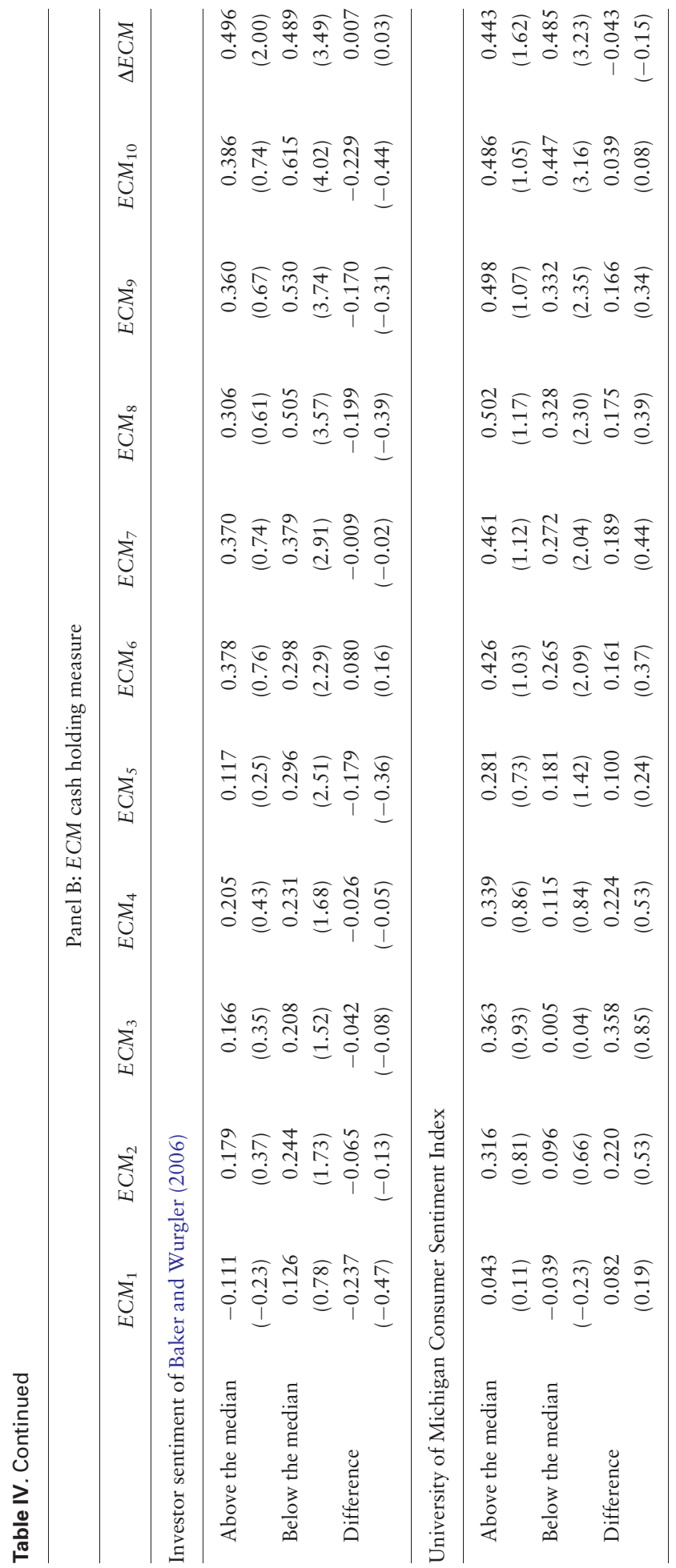


$0.062 \%$ to $1.072 \%$ for $\mathrm{CH}$ deciles when investor sentiment is below the median. The ECM portfolios have a similar pattern of the returns to that of $\mathrm{CH}$ portfolios based on the two sentiment indices. More importantly, the FF3 alphas of hedge portfolios $(\triangle C H, \triangle E C M)$ are statistically significant at the $1 \%$ level when sentiment is below the median. Conversely, they are insignificant when sentiment is above the median with only one exception ( $\triangle E C M$ based on the Baker and Wurgler (2006) investor sentiment index). It is interesting to note that the FF3 alphas of ECM hedge portfolio $(\triangle E C M)$ are similar between sentiment above and below the median. The possible explanation might be that excess cash is measured after controlling for size, book-to-market, and other variables. Those variables have been found to be highly related to investor sentiment (Baker and Wurgler, 2006).

In order to further investigate the impact of sentiment on the cash holding effect, we need a more accurate measure of sentiment. Since sentiment cannot be directly observed, it must be estimated from other variables. The Baker and Wurgler (2006) investor sentiment index as the most widely used sentiment measure is estimated as the first principal component from six sentiment proxies. Da, Engelberg, and Gao (2015) and Huang et al. (2015) criticize that this measure reflects the outcome of balancing economic components and is subject to substantial amount of measurement errors. As a result, the Baker and Wurgler (2006) investor sentiment index may fail to produce strong predictors for future stock returns. We therefore need to identify a portfolio that is highly correlated with market-wide sentiment. Breeden, Gibbons, and Litzenberger (1989) develop a maximum correlation portfolio (MCP) approach that calculate the portfolio weights as the proportions of the coefficients in a multiple regression and use the weights to construct the maximum correlation portfolio. This approach can mitigate the downward bias in the coefficient of determination of the regression. Because there is no portfolio whose return is perfectly correlated with sentiment, we follow Jagannathan and Wang (2007) and run the regression of the demeaned sentiment index on monthly excess returns of the $2 \times 3$ equal-weighted MV\&B/ $M$-sorted portfolios to obtain portfolio weights. We then use the weights to form the maximum correlation portfolio of sentiment in order to reduce forecasting errors. ${ }^{10}$

Our regression models are as follows:

$$
\begin{gathered}
R_{\text {High-Low }, t}=a_{0}+a_{1} \text { Sentiment }_{M C P, t-1}+e_{i t}, \\
R_{\text {High-Low }, t}=a_{0}+a_{1} \text { Sentiment }_{M C P, t-1}+a_{2}\left(R_{m, t}-R_{f, t}\right)_{t}+a_{3} S M B_{t}+a_{4} H M L_{t}+e_{i t},
\end{gathered}
$$

where $R_{\text {High-Low,t }}$ is the portfolio return that is long the top three CHs or ECMs deciles and shorts the bottom three corresponding deciles in month $t$ following Baker and Wurgler (2006). Sentiment $t_{M C P, t-1}$ is the returns on maximum correlation portfolio (MCP) of sentiment in month $t-1$.

Table $\mathrm{V}$ reports the estimates for $\mathrm{CH}$ and ECM hedge portfolios based on the two sentiment indices. The coefficients of Sentiment ${ }_{M C P, t-1}$ are significantly negative before and after controlling for the Fama and French (1993) three factors, with only one exception (the marginal significant coefficient of ECM hedge portfolio from the model with the Fama and

10 A number of studies use the MCP approach. For instance, Breeden, Gibbons, and Litzenberger (1989) adopt the MCP approach for aggregate consumption growth. Jagannathan and Wang (2007) use the approach to examine the measurement errors of consumption-based capital asset pricing model. Ferson and Harvey (1993) apply the similar method to measure conditional beta and global risk premier. 
Table V. Regressions of high-minus-low cash portfolios on investor sentiment

At the end of each month of year $t$, we sort stocks into $\mathrm{CH}$ deciles based on their cash-to-assets ratios. The portfolios are held for the subsequent month and rebalanced monthly. To form ECM portfolios, at the end of June of year $t$, we sort stocks into deciles based on stocks' excess cash measured by using accounting data from year $t-1$. The portfolios are held for the subsequent 12 months and rebalanced annually. The dependent variable is the equal-weighted returns of hedge portfolio that is long the top three $\mathrm{CH}$ s or $\mathrm{ECMs}$ deciles and shorts the bottom three $\mathrm{CH}$ or ECMs deciles. The independent variables are the 1-month lagged returns of maximum correlation portfolio (MCP) of investor sentiment and the Fama and French (1993) three factors. We run regression of the demeaned sentiment index on monthly excess returns of the $2 \times 3$ equal-weighted $M V \& B / M$-sorted portfolios to obtain the portfolio weights and use the weight to construct the maximum correlation portfolio of sentiment. We use the Baker and Wurgler (2006) investor sentiment index and the University of Michigan Consumer Sentiment Index to proxy for sentiment. The corresponding $t$-statistics based on Newey and West (1987) standard errors with six lags are in parentheses. The sample period covers from July 1972 to June 2011, except for the Baker and Wurgler (2006) investor sentiment index which ends in December 2010.

\begin{tabular}{|c|c|c|c|c|c|c|c|c|}
\hline \multirow[b]{3}{*}{ Constant } & \multicolumn{4}{|c|}{ Panel A: $\mathrm{CH}_{\text {High }}-\mathrm{CH}_{\text {Low }}$} & \multicolumn{4}{|c|}{ Panel B: $E C M_{\text {High }}-E C M_{L o w}$} \\
\hline & \multicolumn{2}{|c|}{$\begin{array}{l}\text { Investor } \\
\text { sentiment of } \\
\text { Baker and } \\
\text { Wurgler (2006) }\end{array}$} & \multicolumn{2}{|c|}{$\begin{array}{l}\text { University of } \\
\text { Michigan } \\
\text { Consumer } \\
\text { Sentiment Index }\end{array}$} & \multicolumn{2}{|c|}{$\begin{array}{l}\text { Investor } \\
\text { sentiment of } \\
\text { Baker and } \\
\text { Wurgler (2006) }\end{array}$} & \multicolumn{2}{|c|}{$\begin{array}{l}\text { University } \\
\text { of Michigan } \\
\text { Consumer } \\
\text { Sentiment Index }\end{array}$} \\
\hline & $\begin{array}{c}0.007 \\
(3.48)\end{array}$ & $\begin{array}{c}0.011 \\
(6.39)\end{array}$ & $\begin{array}{c}0.009 \\
(4.63)\end{array}$ & $\begin{array}{c}0.011 \\
(6.50)\end{array}$ & $\begin{array}{c}0.003 \\
(3.23)\end{array}$ & $\begin{array}{c}0.005 \\
(4.16)\end{array}$ & $\begin{array}{c}0.004 \\
(4.03)\end{array}$ & $\begin{array}{r}0.005 \\
(4.39)\end{array}$ \\
\hline Sentiment $_{M C P}$ & $\begin{array}{l}-0.866 \\
(-4.46)\end{array}$ & $\begin{array}{c}-0.743 \\
(-6.50)\end{array}$ & $\begin{array}{l}-0.032 \\
(-6.53)\end{array}$ & $\begin{array}{l}-0.021 \\
(-6.84)\end{array}$ & $\begin{array}{l}-0.002 \\
(-2.42)\end{array}$ & $\begin{array}{l}-0.002 \\
(-1.76)\end{array}$ & $\begin{array}{c}-1.073 \\
(-4.25)\end{array}$ & $\begin{array}{c}-0.578 \\
(-2.35)\end{array}$ \\
\hline$R_{m, t}-R_{f, t}$ & & $\begin{array}{c}-0.088 \\
(-1.84)\end{array}$ & & $\begin{array}{c}-0.074 \\
(-1.59)\end{array}$ & & $\begin{array}{l}-0.013 \\
(-0.32)\end{array}$ & & $\begin{array}{c}-0.012 \\
(-0.31)\end{array}$ \\
\hline$S M B$ & & $\begin{array}{c}0.072 \\
(0.79)\end{array}$ & & $\begin{array}{c}0.073 \\
(0.76)\end{array}$ & & $\begin{array}{c}0.050 \\
(0.88)\end{array}$ & & $\begin{array}{r}0.040 \\
(0.69)\end{array}$ \\
\hline$H M L$ & & $\begin{array}{r}-0.850 \\
(-10.71)\end{array}$ & & $\begin{array}{c}-0.734 \\
(-9.58)\end{array}$ & & $\begin{array}{l}-0.315 \\
(-8.19)\end{array}$ & & $\begin{array}{r}-0.285 \\
(-7.61)\end{array}$ \\
\hline
\end{tabular}

French (1993) three factors based on the Baker and Wurgler investor sentiment index). The results confirm that the cash holding effect is strong when both sentiment indices are low. This indicates that sentiment is a significant predictor for the cash holding effect, which is consistent with the argument of Baker and Wurgler (2006).

\subsection{Transaction Costs and Short Selling Costs for Cash Holding Effect}

In order to address the issue of whether the cash holding effect is concentrated in stocks with high costs, we first use a two-way portfolio sorts approach and examine the variations of the cash holding effect across transaction costs and institutional ownership portfolios. Then, we run Fama and MacBeth (1973) cross-sectional regressions to compare the slopes of the cash holding variable for the transaction costs and institutional ownership subgroups. 


\subsubsection{Portfolio sorts}

We sort stocks on their cash holding measures intersected with independent sorts on the transaction costs and short selling costs measures. Consistent with the approaches in Table II, we form the $\mathrm{CH}$-based portfolios on a monthly basis and the ECM-based portfolios on an annual basis. Specifically, at the end of each month of year $t$, we sort stocks into five $\mathrm{CH}$ portfolios based on their cash-to-assets ratio. Also, we sort stocks independently into three transaction and short selling costs portfolios based on their bid-ask spread $(B A)$, price impact $(P I)$, dollar volume $(D V)$, and percentage of institutional ownership (IO). The portfolios are held for the subsequent month. For the ECM-based portfolios, at the end of June of each year $t$, we sort stocks into five portfolios based on their excess cash measure and sort stocks independently into three transaction and short selling costs portfolios. The portfolios are held for the following 12 months and rebalanced annually. Table VI reports the equal-weighted FF3 alphas for the two-way sorted portfolios. Panels A and $\mathrm{B}$ present the results for $\mathrm{CH}$ and ECM portfolios, respectively. The subscript 1 stands for the bottom quintile or tercile and the subscript 5 (3) stands for the top quintile (tercile). $\Delta$ denotes a hedge portfolio that is long the top portfolio and shorts the bottom portfolio.

We find that $\mathrm{CH}_{5} \mathrm{~s}\left(E C M_{5} \mathrm{~s}\right)$ uniformly outperform $\mathrm{CH}_{1} \mathrm{~s}\left(E C M_{1} \mathrm{~s}\right)$ after controlling for the transaction costs and short selling costs measures. The cash holding effect increases monotonically from low costs portfolios to high costs portfolios. Moreover, the abnormal returns of hedge portfolio $\triangle C H(\triangle E C M)$ are higher for $B A_{3}, P I_{3}, D V_{1}$ and $I O_{1}$ portfolios than those for $B A_{1}, P I_{1}, D V_{3}$, and $I O_{3}$ portfolios. For example, the FF3 alphas of $\triangle C H$ is $1.628 \%$ $(t=4.69)$ for $B A_{3}$ and $0.651 \%(t=3.49)$ for $B A_{1}$. That of $\triangle E C M$ is $0.902 \%$ $(t=2.59)$ for $B A_{3}$ and $0.224 \%(t=1.9)$ for $B A_{1}$. Overall, our results suggest that the cash holding effect is more pronounced for stocks with high costs than stocks with low costs.

\subsubsection{Cross-sectional regression}

We next run the following Fama and MacBeth (1973) cross-sectional regressions for the low and high subgroups by splitting the full sample into terciles according to the transaction costs and short selling costs measures:

$$
R_{i, t+1}-R_{f, t+1}=\gamma_{0}+\gamma_{1} C_{i, t}+\gamma_{2} \ln (M V)_{i, t}+\gamma_{3} \ln (B / M)_{i, t}+\gamma_{4} M O M_{i, t}+\varepsilon_{i, t+1},
$$

where $R_{i, t+1}$ is the monthly raw returns from July of year $t$ to June of year $t+1, R_{f, t+1}$ is the risk-free rate, $\mathrm{CH}$ is the cash holding variable, $\ln (\mathrm{MV})$ is the natural logarithm of market capitalization calculated with information available at the end of June of year $t, \ln (B / M)$ is the natural logarithm of the ratio of the book value of equity for the fiscal year ending in year $t-1$ divided by market equity at the end of December of year $t-1, M O M$ is the cumulative compounded stock returns of the previous 6 months from June of year $t$ to May of year $t+1$.

Table VII presents the average slopes from Fama and MacBeth (1973) cross-sectional regressions for each subgroup. Low and High denote the subgroups that comprise stocks in the bottom and the top terciles of $B A, P I, D V$, and $I O$, respectively. High-Low is the difference between the top and the bottom terciles. After controlling for the size, book-to-market and momentum variables, the cash holding variable has strong explanatory power for the High $B A$ and $P I$, and Low $D V$ and $I O$ subgroups for both of the cash holding measures. Moreover, the slopes of $\mathrm{CH}$ and ECM are significantly greater in magnitude for the High $B A$ and $P I$, and Low $I O$ subgroups than those in the Low BA and PI, and High IO 
Table VI. Two-way portfolio sorts on cash holding and transaction costs or short selling costs

At the end of each month of year $t$, we sort stocks into quintiles based on their cash-to-assets $(\mathrm{CH})$ and sort stocks independently into terciles based on their transaction costs and short selling costs proxies. The portfolios are held for the subsequent month and rebalanced monthly. To form excess cash measure(ECM)-based portfolios, at the end of June of each year $t$, we sort stocks into quintiles based on stocks' excess cash measured by using accounting data from year $t-1$, and sort stocks independently into terciles based on their transaction costs and short selling costs proxies. The portfolios are held for the subsequent 12 months and rebalanced annually. We use three transaction costs measures of the quoted bid-ask spread $(B A, \%)$, price impact $\left(P l, 10^{6}\right)$, and dollar volume $(D V, 000)$; and the short selling costs measure of the percentage of institutional ownership (IO). We then report the equal-weighted monthly average abnormal returns from the Fama and French (1993) three-factor model (FF3 alphas). $\mathrm{CH}_{1}$ and $E C M_{1}$ are the bottom cash holding quintiles. $\mathrm{CH}_{3}$ and $E C M_{3}$ are the third cash holding quintiles. $\mathrm{CH}_{5}$ and $E C M_{5}$ are the top cash holding quintiles. $\triangle \mathrm{CH}$ and $\triangle E C M$ are the difference between the top and bottom cash holding quintiles. $B A_{1}, P I_{1}, D V_{1}$, and $I O_{1}$ are the bottom terciles. $B A_{2}$, $P I_{2}, D V_{2}$ and $I O_{2}$ are the middle terciles. $B A_{3}, P I_{3}, D V_{3}$, and $I O_{3}$ are the top terciles. $\triangle B A, \triangle P I, \triangle D$ $V$, and $\Delta I O$ are the difference between the top and the bottom terciles. The corresponding $t-$ statistics based on Newey and West (1987) standard errors with six lags are in parentheses. The sample period covers from July 1972 to June 2011.

\begin{tabular}{|c|c|c|c|c|c|c|c|c|}
\hline & \multicolumn{4}{|c|}{ Panel A: $\mathrm{CH}$ cash holding measure } & \multicolumn{4}{|c|}{ Panel B: ECM cash holding measure } \\
\hline & $\mathrm{CH}_{1}$ & $\mathrm{CH}_{3}$ & $\mathrm{CH}_{5}$ & $\Delta C H$ & $E C M_{1}$ & $\mathrm{ECM}_{3}$ & $\mathrm{ECM}_{5}$ & $\triangle E C M$ \\
\hline \multicolumn{9}{|c|}{$B A$ as a measure of transaction costs } \\
\hline$B A_{1}$ & $\begin{array}{c}0.221 \\
(2.11)\end{array}$ & $\begin{array}{c}0.352 \\
(3.29)\end{array}$ & $\begin{array}{c}0.873 \\
(6.27)\end{array}$ & $\begin{array}{c}0.651 \\
(3.49)\end{array}$ & $\begin{array}{c}0.292 \\
(3.06)\end{array}$ & $\begin{array}{c}0.485 \\
(5.21)\end{array}$ & $\begin{array}{c}0.517 \\
(4.79)\end{array}$ & $\begin{array}{r}0.224 \\
(1.90)\end{array}$ \\
\hline$B A_{2}$ & $\begin{array}{c}-0.176 \\
(-1.33)\end{array}$ & $\begin{array}{c}0.336 \\
(2.58)\end{array}$ & $\begin{array}{c}0.898 \\
(4.78)\end{array}$ & $\begin{array}{c}1.074 \\
(4.78)\end{array}$ & $\begin{array}{c}0.121 \\
(1.04)\end{array}$ & $\begin{array}{c}0.368 \\
(3.39)\end{array}$ & $\begin{array}{c}0.716 \\
(6.38)\end{array}$ & $\begin{array}{c}0.595 \\
(5.52)\end{array}$ \\
\hline$B A_{3}$ & $\begin{array}{c}0.567 \\
(2.35)\end{array}$ & $\begin{array}{c}1.118 \\
(4.11)\end{array}$ & $\begin{array}{c}2.194 \\
(5.82)\end{array}$ & $\begin{array}{c}1.628 \\
(4.69)\end{array}$ & $\begin{array}{c}0.658 \\
(3.20)\end{array}$ & $\begin{array}{c}0.863 \\
(4.70)\end{array}$ & $\begin{array}{l}1.560 \\
(4.06)\end{array}$ & $\begin{array}{c}0.902 \\
(2.59)\end{array}$ \\
\hline$\triangle B A$ & $\begin{array}{c}0.345 \\
(1.46)\end{array}$ & $\begin{array}{c}0.767 \\
(2.77)\end{array}$ & $\begin{array}{c}1.322 \\
(3.52)\end{array}$ & & $\begin{array}{c}0.366 \\
(1.78)\end{array}$ & $\begin{array}{c}0.378 \\
(2.02)\end{array}$ & $\begin{array}{c}1.043 \\
(2.71)\end{array}$ & \\
\hline
\end{tabular}

$P I$ as a measure of transaction costs

\begin{tabular}{ccccccccc}
\hline$P_{1}$ & 0.169 & 0.309 & 0.864 & 0.695 & 0.225 & 0.418 & 0.445 & 0.220 \\
& $(1.50)$ & $(3.47)$ & $(5.23)$ & $(3.41)$ & $(2.46)$ & $(4.71)$ & $(4.06)$ & $(1.89)$ \\
$P I_{2}$ & -0.221 & 0.242 & 0.851 & 1.073 & 0.103 & 0.390 & 0.628 & 0.525 \\
& $(-1.95)$ & $(2.14)$ & $(4.79)$ & $(5.17)$ & $(0.89)$ & $(3.57)$ & $(5.56)$ & $(4.55)$ \\
\multirow{2}{*}{$P I_{3}$} & 0.373 & 0.902 & 1.826 & 1.452 & 0.582 & 0.818 & 1.354 & 0.771 \\
& $(2.02)$ & $(4.91)$ & $(5.45)$ & $(4.87)$ & $(3.06)$ & $(5.05)$ & $(4.39)$ & $(2.85)$ \\
\multirow{2}{*}{$\Delta P I$} & 0.205 & 0.593 & 0.962 & & 0.357 & 0.400 & 0.909 & \\
& $(1.04)$ & $(3.02)$ & $(2.84)$ & & $(1.77)$ & $(2.28)$ & $(2.88)$ & \\
\hline
\end{tabular}


Table VI. Continued

\begin{tabular}{|c|c|c|c|c|c|c|c|c|}
\hline & \multicolumn{4}{|c|}{ Panel A: $\mathrm{CH}$ cash holding measure } & \multicolumn{4}{|c|}{ Panel B: ECM cash holding measure } \\
\hline & $\mathrm{CH}_{1}$ & $\mathrm{CH}_{3}$ & $\mathrm{CH}_{5}$ & $\Delta C H$ & $E C M_{1}$ & $E C M_{3}$ & $E C M_{5}$ & $\triangle E C M$ \\
\hline \multicolumn{9}{|c|}{$D V$ as a measure of transaction costs } \\
\hline$D V_{1}$ & $\begin{array}{c}0.434 \\
(2.42)\end{array}$ & $\begin{array}{c}0.950 \\
(5.52)\end{array}$ & $\begin{array}{l}1.846 \\
(5.64)\end{array}$ & $\begin{array}{c}1.413 \\
(4.69)\end{array}$ & $\begin{array}{c}0.656 \\
(3.67)\end{array}$ & $\begin{array}{c}0.927 \\
(5.93)\end{array}$ & $\begin{array}{c}1.351 \\
(4.50)\end{array}$ & $\begin{array}{l}0.695 \\
(2.57)\end{array}$ \\
\hline$D V_{2}$ & $\begin{array}{l}-0.254 \\
(-2.26)\end{array}$ & $\begin{array}{c}0.212 \\
(1.73)\end{array}$ & $\begin{array}{l}0.866 \\
(4.57)\end{array}$ & $\begin{array}{c}1.121 \\
(5.44)\end{array}$ & $\begin{array}{c}0.081 \\
(0.69)\end{array}$ & $\begin{array}{c}0.304 \\
(3.06)\end{array}$ & $\begin{array}{c}0.643 \\
(5.49)\end{array}$ & $\begin{array}{c}0.562 \\
(5.01)\end{array}$ \\
\hline$D V_{3}$ & $\begin{array}{c}0.135 \\
(1.13)\end{array}$ & $\begin{array}{c}0.290 \\
(3.02)\end{array}$ & $\begin{array}{c}0.914 \\
(4.55)\end{array}$ & $\begin{array}{c}0.779 \\
(3.34)\end{array}$ & $\begin{array}{c}0.158 \\
(1.64)\end{array}$ & $\begin{array}{c}0.399 \\
(4.31)\end{array}$ & $\begin{array}{c}0.427 \\
(3.57)\end{array}$ & $\begin{array}{c}0.269 \\
(2.19)\end{array}$ \\
\hline$\Delta D V$ & $\begin{array}{c}0.299 \\
(1.58)\end{array}$ & $\begin{array}{c}0.660 \\
(3.45)\end{array}$ & $\begin{array}{l}0.932 \\
(2.65)\end{array}$ & & $\begin{array}{l}0.498 \\
(2.59)\end{array}$ & $\begin{array}{c}0.528 \\
(3.10)\end{array}$ & $\begin{array}{c}0.924 \\
(3.00)\end{array}$ & \\
\hline \multicolumn{9}{|c|}{$I O$ as a measure of short selling costs } \\
\hline$I O_{1}$ & $\begin{array}{l}-0.033 \\
(-0.16)\end{array}$ & $\begin{array}{c}0.374 \\
(1.76)\end{array}$ & $\begin{array}{l}1.336 \\
(3.12)\end{array}$ & $\begin{array}{c}1.370 \\
(3.25)\end{array}$ & $\begin{array}{c}0.207 \\
(0.96)\end{array}$ & $\begin{array}{c}0.436 \\
(2.36)\end{array}$ & $\begin{array}{l}1.266 \\
(2.48)\end{array}$ & $\begin{array}{l}1.059 \\
(2.11)\end{array}$ \\
\hline $\mathrm{IO}_{2}$ & $\begin{array}{c}0.037 \\
(0.28)\end{array}$ & $\begin{array}{c}0.514 \\
(4.67)\end{array}$ & $\begin{array}{c}0.886 \\
(6.31)\end{array}$ & $\begin{array}{r}0.849 \\
(4.29)\end{array}$ & $\begin{array}{c}0.381 \\
(3.10)\end{array}$ & $\begin{array}{c}0.522 \\
(4.62)\end{array}$ & $\begin{array}{c}0.744 \\
(6.26)\end{array}$ & $\begin{array}{r}0.364 \\
(3.17)\end{array}$ \\
\hline $\mathrm{IO}_{3}$ & $\begin{array}{c}0.078 \\
(0.62)\end{array}$ & $\begin{array}{c}0.488 \\
(5.00)\end{array}$ & $\begin{array}{c}0.858 \\
(5.91)\end{array}$ & $\begin{array}{c}0.779 \\
(3.71)\end{array}$ & $\begin{array}{r}0.349 \\
(3.04)\end{array}$ & $\begin{array}{c}0.522 \\
(5.30)\end{array}$ & $\begin{array}{c}0.549 \\
(4.68)\end{array}$ & $\begin{array}{r}0.200 \\
(1.46)\end{array}$ \\
\hline$\Delta I O$ & $\begin{array}{c}0.112 \\
(0.55)\end{array}$ & $\begin{array}{c}0.114 \\
(0.52)\end{array}$ & $\begin{array}{l}-0.479 \\
(-1.15)\end{array}$ & & $\begin{array}{c}0.142 \\
(0.63)\end{array}$ & $\begin{array}{c}0.086 \\
(0.42)\end{array}$ & $\begin{array}{l}-0.717 \\
(-1.42)\end{array}$ & \\
\hline
\end{tabular}

subgroups. For example, the slope of cash holding variable is $4.084(t=2.65)$ under the $\mathrm{CH}$ measure and $0.118(t=2.36)$ under the ECM measure for the High-Low BA subgroup. These results confirm the finding in Table VI that the profitability of cash holding trading strategy is costly.

\subsection{Idiosyncratic Volatility for Cash Holding Effect}

In this section, we use both the two-way portfolio sorts approach and Fama and MacBeth (1973) cross-sectional regressions to investigate whether the cash holding effect is strong for stocks with large idiosyncratic volatility.

\subsubsection{Portfolio sorts}

Similar to the formation of the two-way sorts on cash holding and transaction costs, we sort stocks based on their cash holding and idiosyncratic volatility independently. Panels A and B of Table VIII report the equal-weighted FF3 alphas for $\mathrm{CH}$ and ECM portfolios, respectively. The cash holding effect is stronger in high idiosyncratic volatility portfolios than in low idiosyncratic volatility portfolios regardless of the cash holding measures. For instance, the FF alpha is $1.404 \%(t=5.77)$ per month for $\Delta C H$ and $0.837 \%(t=2.9)$ per month for $\triangle E C M$ for high IVOL portfolio $\left(I V O L_{3}\right)$; while the FF alpha is $0.456 \%(t=$ 4.16) per month for $\triangle C H$ and $0.177 \%(t=2.88)$ per month for $\triangle E C M$ for low $I V O L$ portfolio $\left(I V O L_{1}\right)$. The results indicate that stocks with high idiosyncratic volatility produce the stronger cash holding effect than stocks with low idiosyncratic volatility. 
Table VII. Fama and MacBeth (1973) regressions for transaction costs and short selling costs subgroups

For each month from July of year $t$ to June of year $t+1$, we estimate the average coefficients from Fama and MacBeth cross-sectional regressions of the monthly percent excess returns on the cash holding variables plus the control variables for the Low, High, and High-Low transaction costs or short selling costs subgroups. The cash holding variables are cash-to-assets ratio $(\mathrm{CH})$ and excess cash measure $(E C M)$. The control variables are size $(\operatorname{In}(M V)$, book-to-market $(\operatorname{In}(B / M))$, and momentum (MOM). $\ln (M V$ is the natural logarithm of market capitalization calculated with information available at the end of June of year $t . \ln (B / M)$ is the natural logarithm of the ratio of the book value of equity for the fiscal year ending in year $t-1$ divided by market equity at the end of December of year $t-1$. MOM is the cumulative compounded stock returns of the previous 6 months from June of year $t$ to May of year $t+1$. We use three transaction costs measures of the quoted bid-ask spread $(B A, \%)$, price impact $\left(P I, 10^{6}\right)$, and dollar volume $(D V, 000)$; and the short selling costs measure of the percentage of institutional ownership $(I O)$. At the end of each month of year $t$, we sort stocks into three terciles based on their $B A, P I, D V$, and IO. Low represents the bottom subgroup. High represents the top subgroup and High-Low represents the difference between the top and the bottom subgroups. The corresponding $t$-statistics based on Newey and West (1987) standard errors with six lags are in parentheses. The sample period covers from July 1972 to June 2011.

\begin{tabular}{|c|c|c|c|c|c|c|c|c|c|c|}
\hline & Constant & $\mathrm{CH}$ & $\ln (M V)$ & $\ln (B / M)$ & MOM & Constant & $E C M$ & $\ln (M V)$ & $\ln (B / M)$ & MOM \\
\hline & \multicolumn{5}{|c|}{ Panel A: $\mathrm{CH}$ cash holding measure } & \multicolumn{5}{|c|}{ Panel B: ECM cash holding measure } \\
\hline \multicolumn{11}{|c|}{$B A$ as a measure of transaction costs } \\
\hline Low & $\begin{array}{c}0.711 \\
(1.47)\end{array}$ & $\begin{array}{c}1.473 \\
(3.98)\end{array}$ & $\begin{array}{c}0.019 \\
(0.32)\end{array}$ & $\begin{array}{c}0.399 \\
(4.80)\end{array}$ & $\begin{array}{c}0.384 \\
(1.95)\end{array}$ & $\begin{array}{c}0.854 \\
(1.72)\end{array}$ & $\begin{array}{c}0.045 \\
(1.71)\end{array}$ & $\begin{array}{c}0.024 \\
(0.46)\end{array}$ & $\begin{array}{c}0.378 \\
(4.45)\end{array}$ & $\begin{array}{r}0.410 \\
(1.89)\end{array}$ \\
\hline High & $\begin{array}{c}2.522 \\
(4.75)\end{array}$ & $\begin{array}{c}5.553 \\
(3.54)\end{array}$ & $\begin{array}{c}-0.556 \\
(-4.21)\end{array}$ & $\begin{array}{c}0.254 \\
(2.04)\end{array}$ & $\begin{array}{c}0.275 \\
(0.61)\end{array}$ & $\begin{array}{c}2.782 \\
(5.85)\end{array}$ & $\begin{array}{c}0.163 \\
(3.49)\end{array}$ & $\begin{array}{c}-0.608 \\
(-6.85)\end{array}$ & $\begin{array}{c}0.310 \\
(4.16)\end{array}$ & $\begin{array}{r}0.096 \\
(0.64)\end{array}$ \\
\hline High-Low & $\begin{array}{c}1.811 \\
(4.17)\end{array}$ & $\begin{array}{r}4.080 \\
(2.65)\end{array}$ & $\begin{array}{c}-0.575 \\
(-4.33)\end{array}$ & $\begin{array}{c}-0.145 \\
(-1.20)\end{array}$ & $\begin{array}{l}-0.109 \\
(-0.23)\end{array}$ & $\begin{array}{c}1.928 \\
(5.23)\end{array}$ & $\begin{array}{c}0.118 \\
(2.36)\end{array}$ & $\begin{array}{c}-0.632 \\
(-7.13)\end{array}$ & $\begin{array}{c}-0.067 \\
(-0.84)\end{array}$ & $\begin{array}{r}-0.314 \\
(-1.60)\end{array}$ \\
\hline
\end{tabular}

$P I$ as a measure of transaction costs

\begin{tabular}{lcccccccccc}
\hline \multirow{2}{*}{ Low } & 0.623 & 1.810 & 0.017 & 0.396 & 0.426 & 0.797 & 0.064 & 0.009 & 0.327 & 0.562 \\
& $(1.12)$ & $(4.56)$ & $(0.30)$ & $(5.47)$ & $(2.02)$ & $(1.36)$ & $(2.20)$ & $(0.17)$ & $(4.11)$ & $(2.56)$ \\
High & 2.409 & 2.136 & -0.484 & 0.278 & 0.132 & 2.636 & 0.156 & -0.485 & 0.226 & 0.116 \\
& $(4.71)$ & $(5.11)$ & $(-5.00)$ & $(3.59)$ & $(0.71)$ & $(5.10)$ & $(3.97)$ & $(-5.02)$ & $(2.99)$ & $(0.76)$ \\
\multirow{3}{*}{ High-Low } & 1.786 & 0.327 & -0.501 & -0.118 & -0.294 & 1.839 & 0.092 & -0.494 & -0.102 & -0.445 \\
& $(3.74)$ & $(0.74)$ & $(-4.89)$ & $(-1.50)$ & $(-1.26)$ & $(4.05)$ & $(2.10)$ & $(-5.11)$ & $(-1.29)$ & $(-2.11)$ \\
\hline
\end{tabular}

DV as a measure of transaction costs

\begin{tabular}{lcccccccccc}
\hline \multirow{2}{*}{ Low } & 2.394 & 1.983 & -0.478 & 0.267 & 0.011 & 2.528 & 0.151 & -0.438 & 0.219 & 0.174 \\
& $(4.72)$ & $(4.99)$ & $(-4.99)$ & $(3.60)$ & $(0.06)$ & $(4.85)$ & $(3.84)$ & $(-4.37)$ & $(3.04)$ & $(1.03)$ \\
High & 0.342 & 2.049 & 0.061 & 0.411 & 0.255 & 0.542 & 0.077 & 0.049 & 0.345 & 0.318 \\
& $(0.53)$ & $(4.93)$ & $(0.96)$ & $(5.44)$ & $(1.34)$ & $(0.82)$ & $(2.61)$ & $(0.78)$ & $(4.35)$ & $(1.65)$ \\
\multirow{2}{*}{ High-Low } & -2.052 & 0.066 & 0.539 & 0.145 & 0.244 & -1.986 & -0.074 & 0.487 & 0.126 & 0.144 \\
& $(-4.22)$ & $(0.15)$ & $(5.57)$ & $(1.79)$ & $(1.15)$ & $(-4.17)$ & $(-1.64)$ & $(5.15)$ & $(1.61)$ & $(0.71)$ \\
\hline
\end{tabular}

IO as a measure of short selling costs

\begin{tabular}{lrrrrrrrrrrr}
\hline \multirow{2}{*}{ Low } & 1.712 & 2.566 & -0.260 & 0.527 & -0.177 & 1.974 & 0.193 & -0.260 & 0.482 & 0.124 \\
& $(3.41)$ & $(5.49)$ & $(-3.04)$ & $(6.03)$ & $(-1.28)$ & $(3.80)$ & $(3.15)$ & $(-2.87)$ & $(5.53)$ & $(0.90)$ \\
High & 0.638 & 1.386 & 0.027 & 0.212 & 0.323 & 1.095 & 0.041 & -0.024 & 0.112 & 0.327 \\
& $(1.22)$ & $(3.24)$ & $(0.62)$ & $(2.83)$ & $(1.80)$ & $(2.08)$ & $(1.30)$ & $(-0.52)$ & $(1.33)$ & $(1.56)$ \\
High-Low & -1.073 & -1.180 & 0.287 & -0.314 & 0.500 & -0.879 & -0.153 & 0.236 & -0.370 & 0.203 \\
& $(-2.52)$ & $(-2.68)$ & $(3.35)$ & $(-3.89)$ & $(2.80)$ & $(-1.93)$ & $(-2.43)$ & $(2.57)$ & $(-4.40)$ & $(1.06)$ \\
\hline
\end{tabular}


Table VIII. Two-way portfolio sorts on cash holding and idiosyncratic risk

At the end of each month of year $t$, we sort stocks into quintiles based on their cash-to-assets ratio $(\mathrm{CH})$ and sort stocks independently into terciles based on their idiosyncratic volatility measures, and hold the portfolios for the subsequent month. The $\mathrm{CH}$ portfolios are rebalanced monthly. To form excess cash measure (ECM)-based portfolios, at the end of June of each year $t$, we sort stocks into quintile based on their ECM and sort stocks independently into terciles based on their idiosyncratic volatility measure, and hold the portfolios for the subsequent 12 months. The ECM portfolios are rebalanced annually. The idiosyncratic volatility measure $\left(I V O L_{F F 3}\right)$ is estimated as the standard deviations of the regression residuals from the Fama and French (1993) three-factor model using daily stock returns over prior 12 months with a minimum of 100 days. We then report the equal-weighted monthly average abnormal returns from the Fama and French (1993) three-factor model (FF3 alphas). $\mathrm{CH}_{1}$ and $E C M_{1}$ are the bottom cash holding quintile. $\mathrm{CH}_{3}$ and $E C M_{3}$ are the third cash holding quintile $\mathrm{CH}_{5}$ and $E C M_{5}$ are the top cash holding quintile. $\triangle C H$ and $\triangle E C M$ are the difference between the top and bottom cash holding quintiles. $I V O L_{1}$ is the bottom idiosyncratic volatility tercile. $I V O L_{2}$ is the middle idiosyncratic volatility tercile. $I V O L_{3}$ is the top idiosyncratic volatility tercile. $\triangle I V O L$ is the difference between the top and the bottom idiosyncratic volatility terciles. The corresponding $t$-statistics based on Newey and West (1987) standard errors with six lags are in parentheses. The sample period covers from July 1972 to June 2011.

\begin{tabular}{|c|c|c|c|c|c|c|c|c|}
\hline & \multicolumn{4}{|c|}{ Panel A: $\mathrm{CH}$ cash holding measure } & \multicolumn{4}{|c|}{ Panel B: ECM cash holding measure } \\
\hline & $\mathrm{CH}_{1}$ & $\mathrm{CH}_{3}$ & $\mathrm{CH}_{5}$ & $\Delta C H$ & $E C M_{1}$ & $\mathrm{ECM}_{3}$ & $\mathrm{ECM}_{5}$ & $\triangle E C M$ \\
\hline \multirow[t]{2}{*}{$I V O L_{1}$} & 0.393 & 0.613 & 0.849 & 0.456 & 0.460 & 0.639 & 0.637 & 0.177 \\
\hline & $(4.35)$ & $(7.39)$ & $(10.46)$ & $(4.16)$ & $(5.65)$ & $(7.81)$ & $(8.26)$ & $(2.88)$ \\
\hline \multirow[t]{2}{*}{$I_{V O L}$} & 0.068 & 0.523 & 0.915 & 0.847 & 0.298 & 0.440 & 0.669 & 0.370 \\
\hline & $(0.53)$ & $(5.32)$ & $(7.63)$ & $(4.86)$ & $(2.62)$ & $(4.74)$ & $(7.00)$ & (3.28) \\
\hline \multirow[t]{2}{*}{$I V O L_{3}$} & -0.119 & 0.342 & 1.285 & 1.404 & 0.374 & 0.554 & 1.211 & 0.837 \\
\hline & $(-0.52)$ & $(1.48)$ & $(4.52)$ & $(5.77)$ & $(1.69)$ & $(2.56)$ & $(3.49)$ & $(2.90)$ \\
\hline \multirow[t]{2}{*}{$\triangle I V O L$} & -0.512 & -0.270 & 0.435 & & -0.086 & -0.085 & 0.575 & \\
\hline & $(-2.13)$ & $(-1.08)$ & $(1.49)$ & & $(-0.37)$ & $(-0.36)$ & $(1.55)$ & \\
\hline
\end{tabular}

\subsubsection{Cross-sectional regression}

We also run the monthly excess returns in Equation (5) by splitting the full sample into three terciles based on stocks' idiosyncratic volatility. Table IX reports the average slopes for the Low, High, and High-Low idiosyncratic volatility subgroups. It can be observed that the regressions estimate the strong positive average slopes of $\mathrm{CH}$ and $\mathrm{ECM}$ for both of the Low and High idiosyncratic volatility subgroups. In particular, the slopes of $\mathrm{CH}$ and ECM variables are significantly larger in magnitude in the high idiosyncratic volatility subgroup than in the low idiosyncratic volatility subgroup. For instance, the slope of $\mathrm{CH}$ is $2.196(t=5.28)$ and that of ECM is $0.16(t=4.46)$ for the High-Low idiosyncratic volatility subgroup. This is in line with the limits-to-arbitrage hypothesis that arbitrage on the cash holding effect is risky.

\subsection{Cross-Sectional Regression over the Full Sample}

To test the robustness of our cross-sectional regressions, we run Fama and MacBeth (1973) cross-sectional regressions on the full sample. We use the monthly excess returns from July 
Table IX. Fama and MacBeth (1973) regressions for idiosyncratic volatility subgroups

For each month from July of year t to June of year $t+1$, we estimate the average coefficients from Fama and MacBeth cross-sectional regressions of the monthly per cent excess returns on the cash holding variables plus the control variables for the Low, High, and High-Low idiosyncratic volatility subgroups. The cash holding variables are cash-to-assets ratio $(\mathrm{CH})$ and excess cash measure $(E C M)$. The control variables are size $(\ln (M V))$, book-to-market $(\ln (B / M))$, and momentum (MOM). In(MV) is the natural logarithm of market capitalization calculated with information available at the end of June of year $t . \ln (B / M)$ is the natural logarithm of the ratio of the book value of equity for the fiscal year ending in year $t-1$ divided by market equity at the end of December of year $t-1$. MOM is the cumulative compounded stock returns of the previous 6 months from June of year $t$ to May of year $t+1$. The idiosyncratic volatility measures $\left(I V O L_{F F 3}\right)$ is estimated as the standard deviations of the regression residuals from the Fama and French (1993) three-factor model over prior 12 months with a minimum of 100 days. At the end of each month of year $t$, we sort stocks into three terciles based on their $I V O L_{F F 3}$. Low represents the bottom idiosyncratic volatility subgroup. High represents the top idiosyncratic volatility subgroup and High-Low represents the difference between the top and the bottom idiosyncratic volatility subgroups. The corresponding $t$-statistics based on Newey and West (1987) standard errors with six lags are in parentheses. The sample period covers from July 1972 to June 2011.

\begin{tabular}{|c|c|c|c|c|c|c|c|c|c|c|}
\hline & Constant & $\mathrm{CH}$ & $\ln (M V)$ & $\ln (B / M)$ & $M O M$ & Constant & $E C M$ & $\ln (M V)$ & $\ln (B / M)$ & MOM \\
\hline Low & $\begin{array}{c}0.813 \\
(2.66)\end{array}$ & $\begin{array}{c}0.848 \\
(3.10)\end{array}$ & $\begin{array}{l}-0.023 \\
(-0.75)\end{array}$ & $\begin{array}{c}0.189 \\
(3.16)\end{array}$ & $\begin{array}{c}0.746 \\
(3.58)\end{array}$ & $\begin{array}{c}0.865 \\
(3.09)\end{array}$ & $\begin{array}{c}0.043 \\
(2.71)\end{array}$ & $\begin{array}{c}-0.014 \\
(-0.50)\end{array}$ & $\begin{array}{c}0.151 \\
(2.65)\end{array}$ & $\begin{array}{c}0.632 \\
(3.81)\end{array}$ \\
\hline High & $\begin{array}{c}2.578 \\
(5.09)\end{array}$ & $\begin{array}{r}3.043 \\
(7.03)\end{array}$ & $\begin{array}{c}-0.617 \\
(-6.86)\end{array}$ & $\begin{array}{r}0.385 \\
(4.93)\end{array}$ & $\begin{array}{c}0.154 \\
(0.95)\end{array}$ & $\begin{array}{c}2.878 \\
(6.19)\end{array}$ & $\begin{array}{r}0.203 \\
(5.42)\end{array}$ & $\begin{array}{l}-0.589 \\
(-7.32)\end{array}$ & $\begin{array}{r}0.395 \\
(5.57)\end{array}$ & $\begin{array}{r}0.117 \\
(0.89)\end{array}$ \\
\hline High-Low & $\begin{array}{l}1.765 \\
(4.53)\end{array}$ & $\begin{array}{c}2.196 \\
(5.28)\end{array}$ & $\begin{array}{c}-0.594 \\
(-6.99)\end{array}$ & $\begin{array}{c}0.196 \\
(2.50)\end{array}$ & $\begin{array}{l}-0.591 \\
(-2.83)\end{array}$ & $\begin{array}{c}2.012 \\
(5.95)\end{array}$ & $\begin{array}{r}0.160 \\
(4.46)\end{array}$ & $\begin{array}{l}-0.575 \\
(-7.86)\end{array}$ & $\begin{array}{c}0.244 \\
(4.10)\end{array}$ & $\begin{array}{l}-0.515 \\
(-3.50)\end{array}$ \\
\hline
\end{tabular}

of year $t$ to June of year $t+1$ as the dependent variable. The independent variables include: the cash holding proxies of $\mathrm{CH}$ and ECM, the dummy variable of the limits-toarbitrage proxies, the interaction term between a cash holding proxies and a dummy variable of limits-to-arbitrage proxies, and the control variables. The dummy variable is equal to one if a firm's limits-to-arbitrage proxy of $B A, P I, D V, I O$, or $I V O L_{F F 3}$ is above the median, and zero otherwise.

The results are presented in Table X. The coefficients on cash holding proxies are positive and statistically significant at the $1 \%$ level across both of the cash holding measures for all limits-to-arbitrage proxies. Moreover, the interaction terms are significantly positive for $B A, P I$ (marginal significant), and $I V O L_{F F 3}$. The results suggest that firms with high $B A$, $P I$, and $I V O L_{F F 3}$ have the stronger positive relationship between cash holding and returns than firms with low $B A, P I$, and $I V O L_{F F 3}$. Moreover, the interaction terms are negative for $D V$ and $I O$. These indicate that low $D V$ and $I O$ firms have the stronger positive relationship between cash holding and returns than high $D V$ and $I O$ firms. In summary, our results confirm our previous findings that cash holding variables have the stronger explanatory power on returns for stocks with high transaction costs, high short selling costs, and large idiosyncratic volatility than stocks with low costs and risk. 
Table X. Fama and MacBeth (1973) cross-sectional regressions for the full sample

This table reports the average slopes for monthly excess returns from Fama and MacBeth cross-sectional regressions. Panels $A$ and $B$ report the results based on the cash holding proxies of cash-to-assets ratio $(\mathrm{CH})$ and excess cash measure (ECM), respectively. The independent variables are: the cash holding proxies, the dummy variable of the limit-to-arbitrage proxies, the interaction term between a cash holding proxy and a dummy variable of limits-to-arbitrage proxies, and the control variables of size $(\ln (M V))$, book-to-market $(\ln (B / M))$, and momentum (MOM). $\operatorname{In}(\mathrm{MV})$ is the natural logarithm of market capitalization calculated with information available at the end of June of year $t, \ln (B / M)$ is the natural logarithm of the ratio of the book value of equity for the fiscal year ending in year $t-1$ divided by market equity at the end of December of year $t-1$, and $M O M_{i, t}$ is the cumulative compounded stock returns of the previous 6 months from June of year $t$ to May of year $t+1$. We use five limit-to-arbitrage proxies of the quoted bid-ask spread $(B A, \%)$, price impact $\left(P I, 10^{6}\right)$, dollar volume $(D V, 000)$, percentage of institutional ownership (IO), and idiosyncratic risk based on FF3 (IVOL $\left.L_{F F 3}\right)$. The dummy variable is equal to one for a firm with the limit-to-arbitrage proxies above the median and zero otherwise. The corresponding $t$-statistics based on Newey and West (1987) standard errors with six lags are in parentheses. The sample period covers from July 1972 to June 2011.

\begin{tabular}{lllllll}
\hline Constant & $\begin{array}{llll}\text { Cash } \\
\text { holding }\end{array}$ & $\begin{array}{l}\text { Limit-to- } \\
\text { arbitrage }\end{array}$ & Interaction & $\ln (M V)$ & $\ln (B / M)$ & $M O M$ \\
\hline
\end{tabular}

Panel A: $\mathrm{CH}$ cash holding measure

\begin{tabular}{lccccccc}
\hline$B A$ & 1.576 & 1.532 & -0.069 & 0.959 & -0.147 & 0.395 & 0.153 \\
& $(3.68)$ & $(4.37)$ & $(-0.62)$ & $(2.35)$ & $(-2.85)$ & $(5.52)$ & $(1.02)$ \\
$P I$ & 1.177 & 1.740 & 0.019 & 0.660 & -0.059 & 0.428 & 0.135 \\
& $(2.48)$ & $(4.65)$ & $(0.19)$ & $(1.87)$ & $(-1.19)$ & $(6.34)$ & $(0.91)$ \\
$D V$ & 1.198 & 2.257 & -0.073 & -0.379 & -0.052 & 0.429 & 0.152 \\
& $(2.51)$ & $(5.87)$ & $(-0.59)$ & $(-1.10)$ & $(-0.91)$ & $(6.56)$ & $(1.02)$ \\
$I O$ & 1.057 & 2.199 & 0.176 & -0.590 & -0.043 & 0.429 & 0.044 \\
& $(2.22)$ & $(5.24)$ & $(1.78)$ & $(-1.73)$ & $(-0.93)$ & $(6.03)$ & $(0.34)$ \\
IVOLFF3 & 1.586 & 1.217 & -0.334 & 1.282 & -0.126 & 0.381 & 0.129 \\
& $(4.93)$ & $(4.16)$ & $(-1.69)$ & $(3.97)$ & $(-3.25)$ & $(6.35)$ & $(0.94)$ \\
\hline
\end{tabular}

Panel B: ECM cash holding measure

\begin{tabular}{lccccccc}
\hline$B A$ & 1.737 & 0.073 & -0.057 & 0.078 & -0.151 & 0.378 & 0.130 \\
& $(3.84)$ & $(2.83)$ & $(-0.66)$ & $(2.13)$ & $(-2.93)$ & $(5.34)$ & $(0.98)$ \\
$P I$ & 1.483 & 0.074 & 0.026 & 0.053 & -0.090 & 0.356 & 0.150 \\
& $(2.89)$ & $(2.87)$ & $(0.27)$ & $(1.62)$ & $(-1.72)$ & $(4.98)$ & $(1.05)$ \\
$D V$ & 1.464 & 0.124 & -0.120 & -0.048 & -0.072 & 0.350 & 0.163 \\
& $(3.00)$ & $(4.14)$ & $(-0.92)$ & $(-1.45)$ & $(-1.21)$ & $(5.06)$ & $(1.15)$ \\
IO & 1.375 & 0.150 & 0.171 & -0.084 & -0.073 & 0.352 & 0.160 \\
& $(2.84)$ & $(3.41)$ & $(1.90)$ & $(-1.94)$ & $(-1.49)$ & $(4.56)$ & $(1.22)$ \\
\multirow{2}{*}{$I V O L_{F F 3}$} & 1.523 & 0.069 & -0.045 & 0.069 & -0.104 & 0.363 & 0.144 \\
& $(4.81)$ & $(3.77)$ & $(-0.26)$ & $(2.27)$ & $(-2.85)$ & $(5.79)$ & $(1.10)$ \\
& & & & & & &
\end{tabular}




\section{Conclusion}

We examine the role of investor sentiment and limit-to-arbitrage in explaining the positive relationship between cash holding and stock returns documented by Palazzo (2012) and Simutin (2010). Our results show that firms with high cash holdings tend to be small and growth firms. They have high cash flow risk and low percentage of institutional ownership. Consistent with Baker and Wurgler (2006), we find that stock returns of cash holding portfolios are strongly conditional on investor sentiment. In particular, the cash holding effect is significant only when sentiment is low.

Using the two-way portfolio sorts approach and Fama and MacBeth (1973) crosssection regression, we find that the cash holding effect is stronger for stocks with large transaction and short selling costs, and high idiosyncratic volatility than those with low costs and idiosyncratic volatility. The results are robust to various measures of cash holding and transaction costs. Overall, our findings support the investor sentiment and limits-toarbitrage explanations for the cash holding effect, whereby investor sentiment leads to market mispricing on firms with high and low cash holdings. Large transaction and short selling costs, and high idiosyncratic volatility prevent rational investors from exploiting the cash holding effect and eliminating the mispricing.

\section{References}

Ali, A., Hwang, L. S., and Trombley, M. A. (2003) Arbitrage risk and the book-to-market anomaly, Journal of Financial Economics 69, 355-373.

Almeida, H., Campello, M., and Weisbach, M. S. (2004) The cash flow sensitivity of cash, Journal of Finance 59, 1777-1804.

Amihud, Y. (2002) Illiquidity and stock returns: cross-section and time-series effects, Journal of Financial Markets 5, 31-56.

Amihud, Y. and Mendelson, H. (1986) Asset pricing and the bid-ask spread, Journal of Financial Economics 17, 223-249.

Ang, J. S., Cole, R. A., and Lin, J. W. (2000) Agency costs and ownership structure, Journal of Finance 55, 81-106.

Ang, A., Hodrick, R. J., Xing, Y., and Zhang, X. (2006) The cross-section of volatility and expected returns, Journal of Finance 61, 259-299.

Ang, A., Hodrick, R. J., Xing, Y., and Zhang, X. (2009) High idiosyncratic volatility and low returns: international and further US evidence, Journal of Financial Economics 91, 1-23.

Baker, M. and Wurgler, J. (2006) Investor sentiment and the cross-section of stock returns, Journal of Finance 61, 1645-1680.

Baker, M. and Wurgler, J. (2007) Investor sentiment in the stock market, Journal of Economic Perspectives 21, 129-151.

Bali, T. G. and Cakici, N. (2008) Idiosyncratic volatility and the cross-section of expected returns, Journal of Financial and Quantitative Analysis 43, 29-58.

Bali, T. G., Cakici, N., Yan, X. S., and Zhang, Z. (2005) Does idiosyncratic risk really matter?, Journal of Finance 60, 905-929.

Ball, R., Gerakos, J., Linnainmaa, J. T., and Nikolaev, V. V. (2015) Deflating profitability, Journal of Financial Economics 117, 225-248.

Barberis, N., Shleifer, A., and Vishny, R. (1998) A model of investor sentiment, Journal of Financial Economics 49, 307-343.

Bates, T. W., Kahle, K. M., and Stulz, R. M. (2009) Why do US firms hold so much more cash than they used to?, Journal of Finance 64, 1985-2021. 
Brav, A., Heaton, J. B., and Li, S. (2010) The limits of the limits of arbitrage, Review of Finance 14, 157-187.

Breeden, D. T., Gibbons, M. R., and Litzenberger, R. H. (1989) Empirical tests of the consumption-oriented CAPM, Journal of Finance 44, 231-262.

Campbell, J. Y., Hilscher, J., and Szilagyi, J. (2008) In search of distress risk, Journal of Finance 63, 2899-2939.

Cooper, M. J., Gulen, H., and Schill, M. J. (2008) Asset growth and the cross-section of stock returns, Journal of Finance 63, 1609-1651.

Da, Z., Engelberg, J., and Gao, P. (2015) The sum of all fears investor sentiment and asset prices, Review of Financial Studies 28, 1-32.

Davis, J. L., Fama, E. F., and French, K. R. (2000) Characteristics, covariances, and average returns: 1929 to 1997, Journal of Finance 55, 389-406.

Dechow, P. M., Hutton, A. P., Meulbroek, L., and Sloan, R. G. (2001) Short-sellers, fundamental analysis, and stock returns, Journal of Financial Economics 61, 77-106.

Denis, D. J. and Sibilkov, V. (2010) Financial constraints, investment, and the value of cash holdings, Review of Financial Studies 23, 247-269.

Dittmar, A. and Mahrt-Smith, J. (2007) Corporate governance and the value of cash holdings, Journal of Financial Economics 83, 599-634.

Dittmar, A., Mahrt-Smith, J., and Servaes, H. (2003) International corporate governance and corporate cash holdings, Journal of Financial and Quantitative Analysis 38, 111-133.

Doukas, J. A., Kim, C. F., and Pantzalis, C. (2010) Arbitrage risk and stock mispricing, Journal of Financial and Quantitative Analysis 45, 907-934.

Fama, E. F. and French, K. R. (1992) The cross-section of expected stock returns, Journal of Finance 47, 427-465.

Fama, E. F. and French, K. R. (1993) Common risk factors in the returns on stocks and bonds, Journal of Financial Economics 33, 3-56.

Fama, E. F. and MacBeth, J. D. (1973) Risk, return, and equilibrium: empirical tests, Journal of Political Economy 81, 607-636.

Faulkender, M. and Wang, R. (2006) Corporate financial policy and the value of cash, Journal of Finance 61, 1957-1990.

Fazzari, S. M., Hubbard, R. G., and Petersen, B. C. (1988) Financial constraints and corporate investment, Brookings Papers on Economic Activity 1, 141-195.

Ferson, W. E. and Harvey, C. R. (1993) The risk and predictability of international equity returns, Review of Financial Studies 6, 527-566.

Fu, F. (2009) Idiosyncratic risk and the cross-section of expected stock returns, Journal of Financial Economics 91, 24-37.

Gopalan, R., Kadan, O., and Pevzner, M. (2012) Asset liquidity and stock liquidity, Journal of Financial and Quantitative Analysis 1, 1-70.

Harford, J. (1999) Corporate cash reserves and acquisitions, Journal of Finance 54, 1969-1997.

Harford, J., Mansi, S. A., and Maxwell, W. F. (2008) Corporate governance and firm cash holdings in the US, Journal of Financial Economics 87, 535-555.

Hirshleifer, D., Hou, K., Teoh, S. H., and Zhang, Y. (2004) Do investors overvalue firms with bloated balance sheets?, Journal of Accounting and Economics 38, 297-331.

Hirshleifer, D., Teoh, S. H., and Yu, J. J. (2011) Short arbitrage, return asymmetry, and the accrual anomaly, Review of Financial Studies 24, 2429-2461.

Huang, D., Jiang, F., Tu, J., and Zhou, G. (2015) Investor sentiment aligned: a powerful predictor of stock returns, Review of Financial Studies 28, 791-837.

Huang, W., Liu, Q., Rhee, S. G., and Zhang, L. (2010) Return reversals, idiosyncratic risk, and expected returns, Review of Financial Studies 23, 147-168.

Jagannathan, R. and Wang, Y. (2007) Lazy investors, discretionary consumption, and the crosssection of stock returns, Journal of Finance 62, 1623-1661. 
Jegadeesh, N. and Titman, S. (1993) Returns to buying winners and selling losers: implications for stock market efficiency, Journal of Finance 48, 65-91.

Jensen, M. C. (1986) Agency costs of free cash flow, corporate finance, and takeovers, American Economic Review 76, 323-329.

Jensen, M. C. and Meckling, W. H. (1976) Theory of the firm: managerial behavior, agency costs and ownership structure, Journal of Financial Economics 11, 5-50.

Kim, C. S., Mauer, D. C., and Sherman, A. E. (1998) The determinants of corporate liquidity: theory and evidence, Journal of Financial and Quantitative Analysis 33, 335-359.

Lakonishok, J., Shleifer, A., and Vishny, R. W. (1994) Contrarian investment, extrapolation, and risk, Journal of Finance 49, 1541-1578.

Lam, F. E. C. and Wei, K. J. (2011) Limits-to-arbitrage, investment frictions, and the asset growth anomaly, Journal of Financial Economics 102, 127-149.

Lemmon, M. and Portniaguina, E. (2006) Consumer confidence and asset prices: some empirical evidence, Review of Financial Studies 19, 1499-1529.

Li, X. and Luo, D. (2014) Financial constraints, stock illiquidity, and stock returns. University of Nottingham Working paper.

Li, D. and Zhang, L. (2010) Does Q-theory with investment frictions explain anomalies in the cross-section of returns?, Journal of Financial Economics 98, 297-314.

Lintner, J. (1965) Security prices, risk, and maximal gains from diversification, Journal of Finance 20, 587-615.

Lipson, M. L., Mortal, S., and Schill, M. J. (2011) On the scope and drivers of the asset growth effect, Journal of Financial and Quantitative Analysis 46, 1651-1682.

Mashruwala, C., Rajgopal, S., and Shevlin, T. (2006) Why is the accrual anomaly not arbitraged away? The role of idiosyncratic risk and transaction costs, Journal of Accounting and Economics 42, 3-33.

McLean, R. D. (2010) Idiosyncratic risk, long-term reversal, and momentum, Journal of Financial and Quantitative Analysis 45, 883-906.

McLean, R. D. and Pontiff, J. (2016) Does academic research destroy stock return predictability?, Journal of Finance 71, 5-32.

Mitchell, M. and Pulvino, T. (2001) Characteristics of risk and return in risk arbitrage, Journal of Finance 56, 2135-2175.

Mitchell, M., Pulvino, T., and Stafford, E. (2002) Limited arbitrage in equity markets, Journal of Finance 57, 551-584.

Morellec, E. and Schürhoff, N. (2011) Corporate investment and financing under asymmetric information, Journal of Financial Economics 99, 262-288.

Nagel, S. (2005) Short sales, institutional investors and the cross-section of stock returns, Journal of Financial Economics 78, 277-309.

Newey, W. K. and West, K. D. (1987) A simple, positive semi-definite heteroskedasticity and autocorrelation consistent covariance matrix, Econometrica 55, 703-708.

Nikolov, B. and Whited, T. M. (2014) Agency conflicts and cash: estimates from a dynamic model, Journal of Finance 69, 1883-1921.

Novy-Marx, R. (2013) The other side of value: the gross profitability premium, Journal of Financial Economics 108, 1-28.

Opler, T., Pinkowitz, L., Stulz, R., and Williamson, R. (1999) The determinants and implications of corporate cash holdings, Journal of Financial Economics 52, 3-46.

Opler, T. and Titman, S. (1994) Financial distress and corporate performance, Journal of Finance 49, 1015-1040.

Palazzo, B. (2012) Cash holdings, risk, and expected returns, Journal of Financial Economics 104, 162-185.

Pontiff, J. (1996) Costly arbitrage: evidence from closed-end funds, Quarterly Journal of Economics 111, 1135-1151. 
Pontiff, J. (2006) Costly arbitrage and the myth of idiosyncratic risk, Journal of Accounting and Economics 42, 35-52.

Sharpe, W. F. (1964) Capital asset prices: a theory of market equilibrium under conditions of risk, Journal of Finance 19, 425-442.

Sharpe, W. F. and Alexander, G. (1990) Investments 4th Edition, Prentice Hall, Englewood Cliffs, New Jersey.

Shleifer, A. and Vishny, R. W. (1986) Large shareholders and corporate control, Journal of Political Economy 94, 461-488.

Shleifer, A. and Vishny, R. W. (1997) The limits of arbitrage, Journal of Finance 52, 35-55.

Shumway, T. (1997) The delisting bias in CRSP data, Journal of Finance 52, 327-340.

Simutin, M. (2010) Excess cash and stock returns, Financial Management 39, 1197-1222.

Sloan, R. (1996) Do stock prices fully reflect information in accruals and cash flows about future earnings?, Accounting Review 71, 289-315.

Titman, S., Wei, K. C., and Xie, F. (2004) Capital investments and stock returns, Journal of Financial and Quantitative Analysis 39, 677-700.

Xing, Y. (2008) Interpreting the value effect through the Q-theory: an empirical investigation, Review of Financial Studies 21, 1767-1795.

Xu, Y. and Malkiel, B. G. (2003) Investigating the behavior of idiosyncratic volatility, Journal of Business 76, 613-644.

\section{Appendix}

$\mathrm{CH}$ : cash-to-assets ratio, the ratio of cash and marketable securities (data item CHEQ) to the book value of total assets (data item ATQ).

$M V$ : market capitalization of equity, calculated by share price at the end of June in year $t$ times the number of shares outstanding from the CRSP.

$B / M$ : book-to-market equity, the ratio of the book value of equity to the market value of equity. Following Davis, Fama, and French (2000), the book value of equity is calculated as the shareholders' equity (data item SEQ), plus balance sheet deferred taxes and investment tax credits (data item TXDITC) (if available), less the book value of preferred stock (in the following order: data item PSTKRV or data item PSTKL or data item PSTK) from the Compustat. The B/M ratio of year $t$ is the book value of equity for the fiscal year ending in year $t-1$, divided by market value at the end of December in year $t-1$ from the CRSP.

MOM: momentum, computed as the cumulative compounded stock returns of the previous 6 months from June of year $t$ to May of year $t+1$.

CFR: cash flow risk, calculated as the standard deviation of a ratio of operating income before depreciation (data item OIBDP) less the sum of interest expenses (data item $X I N T$ ), income taxes (data item TXT), dividends of preferred shares (data item DVP), and dividends of common shares (data item $D V C$ ) to the book value of total assets over 10 years.

Profit: profitability, computed as the ratio of the operating income before depreciation (data item OIBDP) to the book value of total assets.

Leverage: leverage, the ratio of sum of long-term debt (data item DLTT) and debt in current liabilities (data item $D L C$ ) to the book value of total assets.

NetInv: net investment, the ratio of net investment to total assets. Net investment is calculated as the sum of capital expenditures (data item CAPX) plus acquisitions (data item $S C S T K C$ ) net of sales of property (data item SPPE). 
DivDummy: dividend payout dummy, a dummy variable equals one in years in which a firm pays a common dividend (data item $D V C$ ). Otherwise, the dummy equals zero.

$R \& D$ : research \& development to sales ratio, calculated as the ratio of research \& development expense (data item XRD) to sales (data item SALE).

Acquisition: acquisitions to assets ratio, calculated as the ratio of acquisitions (data item $A Q C)$ to the book value of total assets. 